\title{
Land Based Anti-Ship Missiles: A Complementary Capability for Maintaining Access in an Anti-Access/Area- Denial Environment
}

\author{
A Monograph \\ by \\ MAJ David D. Henderson \\ United States Army
}

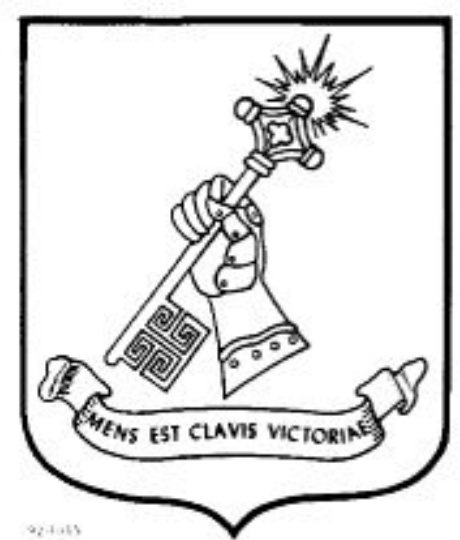

School of Advanced Military Studies

United States Army Command and General Staff College

Fort Leavenworth, Kansas

2014-02 


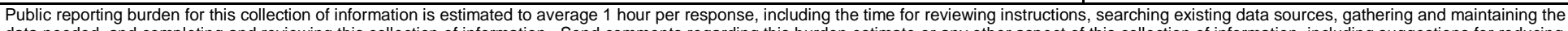

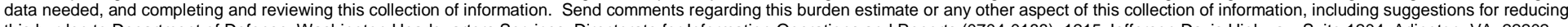

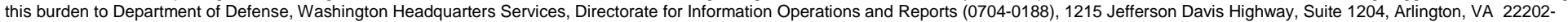

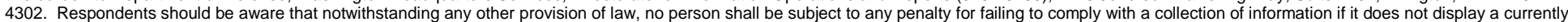
valid OMB control number. PLEASE DO NOT RETURN YOUR FORM TO THE ABOVE ADDRESS.

\begin{tabular}{l|l|l} 
1. REPORT DATE (DD-MM-YYYY) & 2. REPORT TYPE & 3. DATES COVERED (FrOm - To)
\end{tabular}

\begin{tabular}{l|l}
$01-12-2014$ & SAMS Monograph \\
\hline
\end{tabular}

January 2014-December 2014

4. TITLE AND SUBTITLE

Land Based Anti-Ship Missiles: A Complementary Capability for Maintaining Access in an

Anti-Access/Area Denial Environment 5a. CONTRACT NUMBER

5b. GRANT NUMBER

5c. PROGRAM ELEMENT NUMBER

6. AUTHOR(S)

5d. PROJECT NUMBER

5e. TASK NUMBER

MAJ David D. Henderson, U.S. Army

5f. WORK UNIT NUMBER

7. PERFORMING ORGANIZATION NAME(S) AND ADDRESS(ES)

School of Advanced Military Studies (SAMS)

8. PERFORMING ORGANIZATION REPORT

201 Reynolds Avenue

Fort Leavenworth, KS 66027-2134 NUMBER

9. SPONSORING I MONITORING AGENCY NAME(S) AND ADDRESS(ES)

Command and General Staff College

731 McClellan Avenue

Fort Leavenworth, KS 66027-1350

10. SPONSOR/MONITOR'S ACRONYM(S)

CGSC

11. SPONSOR/MONITOR'S REPORT NUMBER(S)

\section{DISTRIBUTION / AVAILABILITY STATEMENT}

Approved for Public Release; Distribution Unlimited

\section{SUPPLEMENTARY NOTES}

\section{ABSTRACT}

A Land Based Anti-Ship Missile (LASM) complements existing Navy and Air Force weapons systems and enhances defensive flexible deterrent options for the National Command Authority (NCA). Complementary military capabilities across domains (air, land, sea, space, cyber) increases strategic and operational agility by presenting a range of options that increase opportunity and reduce risk. China has developed anti-access/area denial (A2AD) capabilities that attempt to neutralize an adversaries technological advantages and prevent access into their "near seas." This monograph uses two case studies to demonstrate an ability to innovate (1973 Arab-Israeli War) with the Assault Breaker program and the ATACMS missile and a failure to innovate (1982 Falklands War) with land based weapons systems in an A2AD environment. This study concluded that the Army should be included in a modern Assault Breaker program that is currently funded between DARPA and the United States Navy. It also determined that the development and deployment of a LASM with a 499-kilometer range employed from a MLRS or HIMARS supports the advocated capability mentioned above, thirteen out of the thirty "critical capabilities” noted in the Joint Operational Access Concept (JOAC), and the ability to maintain a position of continuing advantage by enabling access in contested domains.

\section{SUBJECT TERMS}

Land Based Anti-Ship Missile (LASM), China, Anti-Access/Area Denial (A2AD), Agility, Flexible Deterrent Options (FDO), Air-Sea Battle (ASB), Joint Operational Access Concept (JOAC)

\begin{tabular}{|c|c|c|c|c|c|}
\hline \multicolumn{3}{|c|}{ 16. SECURITY CLASSIFICATION OF: } & \multirow{2}{*}{$\begin{array}{l}\text { 17. LIMITATION } \\
\text { OF ABSTRACT }\end{array}$} & \multirow{2}{*}{$\begin{array}{c}\text { 18. NUMBER } \\
\text { OF PAGES } \\
50\end{array}$} & \multirow{2}{*}{$\begin{array}{l}\text { 19a. NAME OF RESPONSIBLE PERSON } \\
\begin{array}{l}\text { 19b. TELEPHONE NUMBER (include area } \\
\text { code) } \\
\text { 913-758-3302 }\end{array}\end{array}$} \\
\hline $\begin{array}{l}\text { a. REPORT } \\
\text { Unclassified }\end{array}$ & $\begin{array}{l}\text { b. ABSTRACT } \\
\text { Unclassified }\end{array}$ & $\begin{array}{l}\text { c. THIS PAGE } \\
\text { Unclassified }\end{array}$ & & & \\
\hline
\end{tabular}




\section{Monograph Approval Page}

Name of Candidate: MAJ David D. Henderson

Monograph Title: Land Based Anti-Ship Missiles: Complementary Capability for Maintaining Access in an Anti-Access/Area Denial Environment

Approved by:

, Monograph Director

Michael Mihalka, PhD

, Seminar Leader

James W. MacGregor, COL

, Director, School of Advanced Military Studies

Henry A. Arnold III, COL

Accepted this $4^{\text {th }}$ day of December 2014 by:

Robert F. Baumann, PhD

, Director, Graduate Degree Programs

The opinions and conclusions expressed herein are those of the student author, and do not necessarily represent the views of the U.S. Army Command and General Staff College or any other government agency. (References to this study should include the foregoing statement.) 


\begin{abstract}
Land Based Anti-Ship Missiles: A Complementary Capability for Maintaining Access in an AntiAccess/Area Denial Environment by MAJ David D. Henderson, United States Army, 50 pages

A Land Based Anti-Ship Missile (LASM) complements existing Navy and Air Force weapons systems and enhances defensive flexible deterrent options for the National Command Authority (NCA). Complementary military capabilities across domains (air, land, sea, space, cyber) increases strategic and operational agility by presenting a range of options that increase opportunity and reduce risk. China has developed anti-access/area denial (A2AD) capabilities that attempt to neutralize an adversaries technological advantages and prevent access into their "near seas.”

This monograph uses two case studies to demonstrate an ability to innovate (1973 Arab-Israeli War) with the Assault Breaker program and the ATACMS missile and a failure to innovate (1982 Falklands War) with land based weapons systems in an A2AD environment. This study concluded that the Army should be included in a modern Assault Breaker program that is currently funded between DARPA and the United States Navy. It also determined that the development and deployment of a LASM with a 499-kilometer range employed from a MLRS or HIMARS supports the advocated capability mentioned above, thirteen out of the thirty "critical capabilities" noted in the Joint Operational Access Concept (JOAC), and the ability to maintain a position of continuing advantage by enabling access in contested domains.
\end{abstract}




\section{Contents}

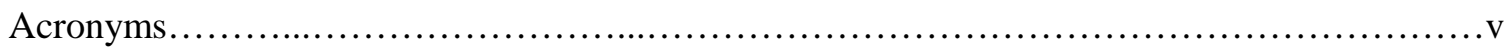

Figures.........................................................................vii

Introduction..........................................................................

Literature Review................................................................................

Research Methodology........................................................... 18

1973 Arab-Israeli War and The Army Tactical Missile System (ATACMS): Successful

Innovation through Complementary Cross Domain Capabilities..............................18

1982 Falklands War: Failure to Innovate With Complementary Cross-Domain

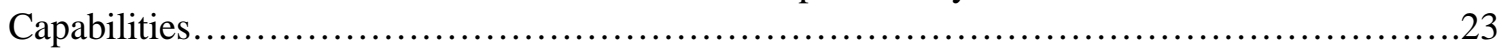

Imagining the Future: An Examination of the Chinese A2AD Threat and Its Implications for a

Land Based Anti-Ship Missile .....................................................

What Kind of LASM and Potential Chinese Reactions....................................38

Conclusions and Recommendations....................................................... 44

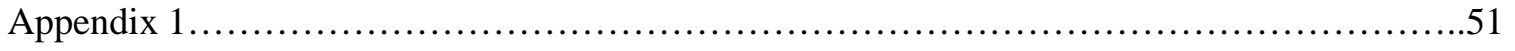

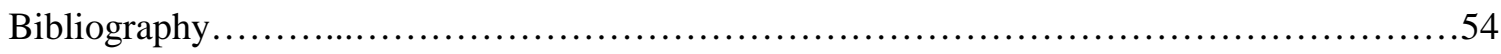




\section{Acronyms}

\begin{tabular}{|c|c|}
\hline $\mathrm{A} 2 / \mathrm{AD}$ & Antiaccess/access denial \\
\hline AMD & Air \& Missile Defense \\
\hline ARCIC & Army Capabilities Integration Center \\
\hline ASB & Air-Sea Battle \\
\hline ASM & Anti-ship missile \\
\hline ASBM & Anti-ship Ballistic Missile \\
\hline ASW & Anti-ship warfare \\
\hline ATACMS & Army Tactical Missile System \\
\hline $\mathrm{BCD}$ & Battlefield coordination detachment \\
\hline BCE & Battlefield coordination element \\
\hline BCT & Brigade Combat Team \\
\hline $\mathrm{C} 2$ & Command and Control \\
\hline CARL & Combined Arms Research Library \\
\hline CGSC & U.S. Army Command and General Staff College \\
\hline CSBA & Center for Strategic and Budgetary Assessment \\
\hline DARPA & Defense Advanced Research Projects Agency \\
\hline FA & Field Artillery \\
\hline FDO & Flexible Deterrent Option \\
\hline FSCL & Fire Support Coordination Line \\
\hline HIMARS & High Mobility Artillery Rocket System \\
\hline IADS & Integrated Air Defense System \\
\hline $\mathrm{IMF}$ & Intermediate Missile Force \\
\hline JOA & Joint Operational Area \\
\hline JOAC & Joint Operational Access Concept \\
\hline
\end{tabular}




$\begin{array}{ll}\text { JSAK } & \text { Joint Attack of the Second Echelon } \\ \text { J-SEAD } & \text { Joint Suppression of Enemy Air Defenses } \\ \text { LASM } & \text { Land-based anti-ship missile } \\ \text { MCBL } & \text { Mission Command Battle Lab } \\ \text { MRL } & \text { Multiple Rocket Launcher } \\ \text { MLRS } & \text { Multiple Launch Rocket System } \\ \text { MMAS } & \text { Master of Military Art and Science } \\ \text { MTOE } & \text { Modified Table of Organization and Equipment } \\ \text { OASuW } & \text { Offensive Anti-Surface Warfare } \\ \text { PEO-MS } & \text { Program Executive Office Missiles and Space } \\ \text { PLA } & \text { People's Liberation Army } \\ \text { PLA Navy } & \text { People’s Liberation Army Navy } \\ \text { PRC } & \text { People’s Republic of China } \\ \text { RMA } & \text { Revolution in Military Affairs } \\ \text { SAMS } & \text { School of Advanced Military Studies } \\ \text { SEAD } & \text { Suppression of Enemy Air Defenses } \\ \text { SLOC } & \text { Sea lines of communication } \\ \text { TA } & \text { Target Acquisition } \\ \text { TRADOC } & \text { Training and Doctrine Command } \\ \text { Theater Security Cooperation Plan }\end{array}$




\section{Figures}

Figure 1. Revolutions in Military Affairs and Military Revolutions..........................12

Figure 2. Graphical depiction of disputed South China Sea territory.........................32 


\section{Introduction}

In order to credibly deter potential adversaries and to prevent them from achieving their objectives, the United States must maintain its ability to project power in areas in which our access and freedom to operate are challenged.

\section{-Department of Defense, Sustaining U.S. Global Leadership: Priorities for the $21^{\text {st }}$ Century Defense}

Lieutenant General H.R. McMaster, Director of the Army Capabilities Integration Center, advocates that the Army should develop capabilities that "can project power from land into the air and sea domains.” An implication for the Army of 2030 from Unified Quest stated that the “Army’s ability to contribute to power projection in anti-access and area denial (A2AD) environments requires improved technology....these capabilities could include a land based antiship missile (LASM)." ${ }^{2}$ This paper will argue that the U.S. Army’s acquisition of LASM supports these capabilities, enhances defensive flexible deterrent options (FDOs), supports the innovation needed to maintain a position of continuing advantage in contested domains, and supports thirteen of the thirty "critical capabilities" directed in the Joint Operational Access Concept (JOAC). ${ }^{3}$ The deployment of a LASM with a 499km range interoperable with existing M270A1 Multiple

${ }^{1}$ LTG H.R. McMaster, “Thinking About Future War” (lecture, Command and General Staff College, Fort Leavenworth, KS, August 14, 2014).

${ }^{2}$ U.S. Department of Defense, Unified Quest 2013: Deep Future Wargame 2030-2040 Executive Report (Carlisle Barracks, PA: US Army War College, 2013), 24.

${ }^{3}$ The Joint Operational Access Concept (JOAC) is how the United States joint force will operate in response to $\mathrm{A} 2 \mathrm{AD}$ challenges. It is the overarching concept that describes the capabilities and tenants that govern the development of both Air-Sea Battle and Joint Concept for Entry Operations. From U.S. Department of Defense, Joint Operational Access Concept. (Washington, DC: Government Printing Office, 2012.) 1. Refer to Appendix A for a listing of these capabilities and how a LASM supports them. Accessed on March 26, 2014, http://www.defense.gov/pubs/pdfs/joac_jan\%202012_signed.pdf 
Launch Rocket System (MLRS) and M142 High Mobility Artillery Rocket System (HIMARS) is a technological innovation supported in Revolution in Military Affairs (RMA) literature.

A RMA is a theoretical term used by scholars to describe major innovations that shaped strategy, organization, tactics, and technologies of warfare. ${ }^{4}$ William Murray and MacGregor Knox state, “military organizations embark upon a RMA by devising new ways of destroying their opponents.” ${ }^{5}$ In order to do this, they must recognize and anticipate changes in the operating environment across the full political, social, and military spectrum. ${ }^{6}$ Innovation using scenario planning to develop complementary military capabilities is one method used for anticipating changes in the operating environment. Complementary military capabilities across domains (air, land, sea, space, cyber) increases strategic and operational agility by presenting a range of options that increase opportunity and reduce risk. ${ }^{7}$ This agility enables a military to maintain a position of continuous advantage that meets the challenges of emergent events and behaviors of actors in the contested domains of the complex operating environment. Though there is no technological solution that will change the nature of war, nations must successfully innovate against specific threats and capabilities in order to remain agile.

The research question that guided this study is, "What are the advantages and disadvantages of the United States Army acquiring a land based anti-ship missile (LASM) and employing it in the Western Pacific, given complementary capabilities already possessed in the

${ }^{4}$ MacGregor Knox and William Murray, The Dynamics of Military Revolution, 13002050 (London, England: Cambridge University Press, 2001), 1-14.

${ }^{5}$ Ibid., 12.

${ }^{6}$ Ibid., 14.

${ }^{7}$ A senior military leader speaking in a non-attribution forum to the School of Advanced Military Studies defined agility as "being where you need to be, when you need to be there, in advance of the anticipated need, in order to achieve a position of relative advantage.” 
Navy and Air Force?” A LASM has the potential to: (1) increase the Combatant Commander’s options for flexible deterrence in Phase 0 (Shape) operations; (2) support the central idea of the Joint Operational Access Concept— that complementary capabilities across domains create a synergy that "enhances the effectiveness and compensates for the vulnerability of the others;" and (3) protect intermediate staging bases (ISB) and long sea lanes of communication (SLOC) into any western Pacific joint operational area (JOA). ${ }^{8}$

Flexible deterrent options (FDO) provide the United States' a scalable response to any potential threat. The deployment of an American LASM in this region provides an additional targeting predicament for the PLA Navy in the event of a regional contingency and supports both Ashby’s Law of Requisite Variety and Dorner's efficiency diversity. ${ }^{9}$ According to Ashby, only “variety can destroy variety.” This system is both an offensive and defensive Anti-Access/Area Denial (A2AD) capability that provides a measure of A2AD parity against Chinese systems and may deter PLA Navy aggression in contested areas and sea lines of communication. The 2012 Army Strategic Planning Guidance directed that the U.S. Army, in conjunction with its Joint, Interagency, Intergovernmental, Multinational (JIIM) partners, prevent large-scale conflict through credible deterrence. The increasing contest for resources, control of the East and South China Seas, and the ability to transit commerce along these seas and straits reinforces the need for

${ }^{8}$ JP 5-0 defines the six-phase model as shape, deter, seize the initiative, dominate, stability, and enable civil authority. It defines shape as "Joint and multinational operationsinclusive of normal and routing military activities; and various interagency activities are performed to dissuade or deter potential adversaries and to assure or solidify relationships with friends and allies.” Joint Publication (JP) 5-0 Joint Operation Planning (Washington, DC: Government Printing Office, 2011), xxiii.

${ }^{9}$ Efficiency diversity is a capability or situation that "offers many different possibilities (diversity) for actions that have a high probability of success (efficiency). From Deitrich Dorner, The Logic of Failure: Recognizing and Avoiding Error in Complex Situations (Perseus Books Group: Cambridge, MA, 1996), 53-54. 
flexible deterrents to Chinese aggression that threatens the military or economic prosperity of regional partners.

For scholars, military planners, and doctrine writers, the Land Based Anti-Ship Missile (LASM) debate matters. An increasing body of literature seeks to advance LASMs as an important, but missing, piece to counter Chinese military aggression and aid the United States’ in overcoming A2AD challenges. ${ }^{10}$ To date, comparatively little research has been done to prove why a land system is needed as a complementary asset to current Naval and Air Force capabilities, how a LASM supports the JOAC, and whether a LASM has theoretical support in revolution in military affairs literature. This paper argues that the adoption of a land based antiship missile directly supports the joint synergy and overlapping capabilities needed in future joint forces directed in the Capstone Concept for Joint Operations: Joint Force 2020 (CCJO), specifically that it "improves capabilities to defeat anti-access and area denial threats." ${ }^{11} \mathrm{~A}$ LASM supports thirteen of thirty critical capabilities directed in the JOAC, provides both and offensive and defensive flexible deterrent option to the Combatant Commander, protects American interests from sea-borne attack, and enables innovation in support of key defense strategy guidance and concepts.

This monograph is presented in eight parts. Part I includes the background, purpose, and significance, and organization of the study. Part II is a literature review of the theoretical foundation of this paper, including revolutions in military affairs and their impact on defense scenario planning. Edward Luttwak and Everett Dolman’s views on strategy demonstrate how a

${ }^{10}$ Examples of this literature include Jim Thomas, "Why the U.S. Army Needs Missiles." Foreign Affairs, April 3, 2013, accessed June 23, 2014, http://www.foreignaffairs.com/articles/139119/jim-thomas/why-the-us-army-needs-missiles and Terrence K. Kelly, Anthony Atler, Todd Nichols, and Lloyd Thrall, Employing Land-Based AntiShip Missiles in the Western Pacific (Santa Monica, CA: RAND Corporation, 2013), iii.

${ }^{11}$ U.S. Department of Defense, Capstone Concept for Joint Operations: Joint Force 2020 (Washington, DC: Government Printing Office, 2012), 11. 
LASM enables strategic and operational agility and the ability to maintain a position of continuing advantage. Part III presents the research methodology. Part IV presents case studies detailing successful innovation using scenario planning, the development of Air Land battle, and the introduction of the Army Tactical Missile System (ATACMS) in the 1980s. It discusses the interplay of theory (Soviet Deep Battle), history (1973 Arab-Israeli War), and doctrine (AirLand Battle) for the development of the ATACMS missile as an Army tool to complement Air Force capabilities. Part V reviews a negative case study on the failure to innovate and develop a complementary Land Based Anti-Ship Missile out of the lessons learned from the 1982 Falklands War. Part VI is a counterfactual analysis of a China threat scenario both with and without a LASM utilizing scenario planning. Part VII is an examination of different development and integration options for a LASM into Army formations, and potential Chinese reactions to the deployment of this system. Part VIII provides a summary of the entire study, conclusions, and recommendations for further research.

\section{Literature Review}

This literature review is divided into five sections: (1) background; (2) a discussion of the theoretical framework of this study — revolution in military affairs (RMA) and its impact on innovation and strategic and operational agility; (3) review of Edward N. Luttwak's views on strategy, the strategic paradox, and the implications for military innovation; (4) Everett Doleman's Pure Strategy demonstrates the need to maintain a position of continuous advantage and its implications for innovation and the development of a LASM; and (5) a review of scenario planning literature and its impact on military innovation. The purpose of this literature review is to present a theoretical structure for the case studies which demonstrate the need to innovate and build cross-domain complementary capabilities in order to increase strategic and operational agility for an uncertain complex operating environment. 


\section{Background}

Potential adversaries have noted that the United States’ decisive early military victories in Iraq and Afghanistan benefited from the unimpeded movement of personnel, logistics, and equipment into the theater of operations. The joint staging, reception, and onward integration (JSROI) of the force during these wars were essentially unopposed. However, the JOAC noted that a combination of inexpensive technologies and the proliferation of weapons into contested areas and littorals will challenge projection of U.S. forces in the near to medium term. ${ }^{12}$ China, for example, has deployed weapons over the last five years in an attempt to negate US military technological advantages and the ability to operate east of the first island chain. These included diesel submarines with wake homing torpedoes, radiation missiles that target airborne sensors, anti-satellite munitions, and anti-ship cruise and ballistic missiles. ${ }^{13}$

James R. Holmes and Toshi Yoshihara, in "Red Star Over the Pacific: China’s Rise and the Challenge to U.S. Maritime Strategy,” point to what former Chinese President Hu Jintao

${ }^{12}$ Force projection: "The ability to project the military instrument of national power from the United States or another theater, in response to requirements for military operations. From U.S. Department of Defense, Air-Sea Battle: Service Collaboration to Address Anti-Access and Area Denial Challenges (Washington, DC: Government Printing Office, 2013$), 4$.

${ }^{13}$ The First Island Chain is a line of islands from Japan, Kuril Islands, Ryukyu Islands, Thailand, Borneo, the Philippines and the Malay Peninsula. Defeating Anti-Access/Area Denial capabilities is about access. There are two types of access. Operational Access is the ability to project military force into an operational area with sufficient freedom of action to accomplish the mission. Its purpose is to support the strategic goals of the United States, including access to the global commons for commerce, positioning forces overseas to "manage crisis and prevent war, or defeat an enemy in war," while Assured Access is the "unhindered national use of the global commons and select sovereign territory, waters, airspace and cyberspace, achieved by projecting all the elements of national power.” From U.S. Department of Defense, Joint Operational Access Concept, 40-44. 
called the "Malacca predicament." The uninterrupted flow of commerce and natural resources is of strategic importance to the Chinese regime and controlling the Straits through patrolling and sea basing agreements is a key objective in any future conflict over Taiwan. ${ }^{14}$ A LASM provides both an offensive and a defensive option to enable access and defend key sea lines of communication in the event of a Chinese attempt to seize the Malaccan Straits during an invasion of Taiwan.

Air-Sea Battle and Joint Entry concepts are predicated on intermediate staging bases (ISB) to enable power projection in the specific Joint Area of Operations (JOA). ${ }^{15}$ Chinese capabilities such as the DF-21 are designed to prevent Naval and Air Force operational access into the region. ${ }^{16}$ The 2012 DSG entitled "Sustaining U.S. Global Leadership: Priorities for 21st Century Defense" specifically tasked the US military to project power despite A2AD. Research institutions, including RAND and the Center for Strategic Budgetary Analysis (CSBA), have indicated that intermediate staging bases, naval, and air assets would be threatened by current Chinese missile defenses and naval capabilities in the event of any potential contingency

${ }^{14}$ Toshi Yoshihar and James R. Holmes, Red Star Over The Pacific: China's Rise and the Challenge to U.S. Maritime Strategy (Annapolis, MD: Naval Institute Press, 2010), 88.

${ }^{15}$ Air-Sea Battle (ASB) is a "limed objective concept that describes what is necessary for the joint force to sufficiently shape A2/AD environments to enable concurrent follow-on power projection operations." 15 Unlike Air Land battle that primarily synchronized the efforts of the land and air domains, the Air-Sea Battle concept attempts to unite the efforts of all five domains of warfare (land, air, sea, space, and cyberspace). Forcible entry is the "projection of land forces onto hostile territory in the face of armed opposition. The subsequent land operations may vary in scope and duration, from small scale raids to sustained campaigns.” U.S. Department of Defense, Joint Operational Access Concept, 6.

${ }^{16}$ The DF-21 has a reported range of over $2,000 \mathrm{~km}$ and is also has an unverified ability to hit ships while underway. From S. Chandrashekar, N. Genesh, C.R. Raghunath, Rajaram Nagappa, N. Ramani and Lalitha Sundaresan, China's Anti-Ship Ballistic Missile Game Changer in the Pacific Ocean. International Strategic \& Security Studies Programme (ISSSP), accessed March 22, 2014, http://isssp.in/wp-content/uploads/2013/01/2011-november-r-5-chinas-anti-shipballistic-missile-report2.pdf 
operation. ${ }^{17}$ Chinese military literature views the enemy as a system of four concentric rings and will concentrate pre-emptive first strike capability on enemy command and control systems and logistical nodes within the first and second rings, which includes both Japan and Guam. ${ }^{18}$ RAND and CSBA advocate for the Army to acquire a land based anti-ship missile to enable Shape (Phase 0) joint and multinational operations and to provide the United States Pacific Commander a scalable option to enable freedom of action in the western Pacific region. ${ }^{19}$ Currently, the United States military only has ASM capability in the Navy and Air Force.

The ability to project power across sea lines of communication will be a critical part of any rebalance to the Pacific. The JOAC projects that the proliferation of A2AD capabilities will place an increasing strain on America's ability to project power in the global commons. ${ }^{20}$ American economic interests are inexorably linked to their ability to project power into the sea domain around the globe. However, U.S. Army combat power has increasingly relocated from Europe and Asia to North America since the end of the Cold War. China has developed its “counter-intervention” strategy, with its pillars of active defense and modernization, in an attempt

${ }^{17}$ Terrence K. Kelly, Anthony Atler, Todd Nichols, and Lloyd Thrall, Employing LandBased Anti-Ship Missiles in the Western Pacific (Santa Monica, CA: RAND Corporation, 2013), 4.

${ }^{18}$ James Mulvenon and David Finkelstein, China's Revolution in Doctrinal Affairs: Emerging Trends in the Operational Art of the Chinese People's Liberation Army (CNA Corporation: Alexandria, VA), 262.

${ }^{19}$ United States Pacific Command (USPACOM) is one of six Unified Combatant Commands that are organized on a geographical basis. USPACOM is composed of the US Pacific fleet, US Pacific Air Forces, U.S. Army Pacific, and the U.S. Marine Forces, Pacific.

${ }^{20}$ The global commons is "an area of air, sea, space, and cyberspace that belong to no one state." From Barry Posen, "Command of the Commons: The Military Foundation of U.S. Hegemony,” International Security, 28: 3 (Summer): 8, accessed March 26, 2014, http://web.mit.edu/ssp/people/posen/commandofthecommons.pdf 
to negate the technological advantages of any potential adversary and prevent foreign militaries from intervening in a conflict in the region. ${ }^{21}$

Argentina utilized anti-ship missiles during the 1982 Falklands War in an attempt to prevent access. As a result, they severely damaged a British destroyer and caused the British Navy to operate almost 320 kilometers from their targets due to the ASM threat. ${ }^{22}$ From this campaign, the PLA derived many lessons learned applicable to any cross strait conflict. In addition to the value of the ASM, the Chinese focused on the Argentinean failure to attack the 8,000 mile British supply line, their failure to attack the British intermediate staging base in the Ascension Islands, and the Argentinean usage of A2AD munitions and tactics to attack a technologically superior opponent. ${ }^{23}$

Chinese scholars and military members heralded the potential development and deployment of a LASM as confirmation of United States intent to create a "far blockade" that will attempt to bottle their regional aspirations within the first island chain. The PLA Navy see the South China Sea as their "near seas" and have submitted claims that encroach upon the boundaries of their neighbors. The development and deployment of a land based anti-ship missile in the Western Pacific would provide an additional measure to ensure freedom of access on the global commons, strengthen partnerships with countries threatened by PLA Navy activity, and employ “the same inexpensive...technologies [used in China's anti-access/area-denial strategy] to significantly raise the cost of a conflict for China, and should deterrence fail, to limit China's

${ }^{21}$ Counter-intervention is a subset of Chinese active defense doctrine that attempts to prevent an outside nation from entering a territorial dispute east of the First Island Chain.

${ }^{22}$ Max Hastings and Simon Jenkins, The Battle of the Falklands (New York: W.W. Norton, 1983), 296-297.

${ }^{23}$ Andrew Schobell, David Lai and Roy Kamphausen, Strategic Studies Institute, Chinese Lessons From Other Peoples’ Wars (Carlisle, PA: US Army War College, 2011), 4. 
ability to inflict damage off the Asian mainland.”24 This would level the disparity in missile capability and presents an A2AD "mutually assured destruction” situation that presents a measure of parity in the region.

\section{Theoretical Foundations for Military Innovation}

Military organizations embark upon an RMA by devising new ways of destroying their opponents. To do so, they must come to grips with fundamental changes in the social, political, and military landscapes; in some cases they must anticipate those changes. Revolutions in military affairs require the assembly of a complex mix of tactical, organizational, doctrinal, and technological innovations in order to implement a new conceptual approach to warfare or to a specialized sub-branch of warfare

-MacGregor Knox and William Murray in The Dynamics of Military Revolution, 1300-2050

An analysis of revolution in military affairs (RMA) literature will inform the theoretical basis of this study; specifically, how countries innovate to increase operational and strategic agility. ${ }^{25}$ The case studies demonstrate that a LASM will provide a complementary capability to existing United States Air Force and Naval systems that enable access to contested JOAs. An RMA is a theoretical term that gained popularity within the Department of Defense after Andrew Marshall and the Office of Net Assessment in the Pentagon published "Military Technical Revolution” in 1992. This paper describes major organization, tactics, and technological developments under a military revolution. ${ }^{26}$ MacGregor Knox and William Murray believe

${ }^{24}$ Ibid.

${ }^{25}$ It is important to denote the difference between military revolutions from a revolution in military affairs. Knox and Murray state that there were five overarching military revolutions since the 1700 s and under each military revolution there "associated and resultant” RMAs. For example, military revolution 5: nuclear and ballistic missile delivery systems had RMAs including precision guided weapons, stealth, computerization of the munitions, and increased lethality of conventional munitions. Knox and Murray believe that the current notions of RMA trace their conceptual roots back to "early modern historians and military theorists." From MacGregor Knox and William Murray, The Dynamics of Military Revolution, 1300-2050, 1-13.

${ }^{26}$ Ibid. 
technology alone is not the catalyst to drive a revolution in military affairs and that the revolution may take place over the course of many decades. It emerges from "evolutionary problem-solving directed at [a] specific theater of war against a specific enemy.” ${ }^{27}$ In other words, innovation emerges from analyzing the capabilities of real opponents with actual capabilities "in pursuit of actual strategic objectives.”28

The history of western militaries since 1700 demonstrates that there are periods of violent change followed by periods of relative calm in which militaries adapt to their changed environment—punctuated equilibrium. ${ }^{29}$ Within the five historical military revolutions (shown in Figure 1 below) are the development of the major elements of RMA, including new doctrine, organizations, and technologies. One example is Soviet operational art that informed technological development and doctrine of the Soviet Union and Germany in the World War I and II interwar years. The American Assault Breaker program presents another example of military innovation; in this case, concepts supporting conflict between nuclear armed nations under military revolution five (see Figure 1 below). This program developed short-range ballistic missiles with "clouds of precision sub-munitions" to target follow on echelons of the Soviet army on the battlefields of Western Europe. It led to the development of the Army Tactical Missile System (ATACMS)—a complementary capability to Air Force systems that were doctrinally templated to attack echelons beyond the 48-hour time horizon. ${ }^{30}$ Unlike the RMAs that emerged

${ }^{27}$ Ibid., 192.

${ }^{28}$ Ibid.

${ }^{29}$ Clifford J. Rogers, “The Military Revolutions of the Hundred Years' War." Journal Of Military History 57, no. 2: 241-278. America: History and Life with Full Text, accessed July 10, 2014, http://www. connection.ebscohost.com/c/book-reviews/51701550/essays-medieval.

${ }^{30}$ Ibid., 4 and Boyd L. Dastrup, Modernizing the King of Battle 1973-1991. USAFACS Historical Monograph Series (Fort Sill, Oklahoma: Center of Military History, 2003), 2. 
in 1917 after three years of slaughter in World War I, the development of ATACMS was innovation to improve agility before conflict. ${ }^{31}$ The development of a Land Based Anti-Ship missile is recognition of the need to innovate to meet the challenges of an $\mathrm{A} 2 \mathrm{AD}$ operating environment.

\begin{tabular}{|lll|} 
Figure 1. Revolutions in Military Affairs and Military Revolutions \\
Time Period & Military Revolution & RMAs \\
\hline 17th Century & $\begin{array}{l}\text { 1. Modern state and } \\
\text { modern military institutions }\end{array}$ & $\begin{array}{l}\text { 1. Dutch and Swedish tactical reforms, } \\
\text { French tactical and organizational reforms, } \\
\text { naval revolution, Britain's financial } \\
\text { revolution } \\
\text { 2. French military reforms following the } \\
\text { Seven Years' War }\end{array}$ \\
\hline $\begin{array}{l}\text { Late 18th-19th } \\
\text { 18th-19th }\end{array}$ & 2. French Revolution & $\begin{array}{l}\text { 3. National political and economic } \\
\text { mobilization, Napoleonic Warfare }\end{array}$ \\
Century & 3. Industrial Revolution & $\begin{array}{l}\text { 4. Financial and economic power based on } \\
\text { Industrialization (Britain); }\end{array}$ \\
& & $\begin{array}{l}\text { 5. Technological revolution in land warfare } \\
\text { and transport (telegraph, artillery, etc) } \\
\text { 6. Fisher Revolution in naval warfare }\end{array}$ \\
\hline $\begin{array}{l}\text { Early 20th } \\
\text { Century }\end{array}$ & 4. WWI and the combination & $\begin{array}{l}\text { 7. Combined arms tactics, strategic } \\
\text { bombing, carrier warfare, radar, signals } \\
\text { intelligence, submarine warfare etc }\end{array}$ \\
\hline $\begin{array}{l}\text { Mid to Late } \\
\text { 20th Century }\end{array}$ & $\begin{array}{l}\text { 5. Nuclear Weapons and } \\
\text { Ballistic Missiles }\end{array}$ & $\begin{array}{l}\text { 8. Precision reconnaissance and strike, } \\
\text { stealth, C3I, increased lethality of } \\
\text { "conventional" munitions }\end{array}$ \\
\hline
\end{tabular}

Figure 1. Revolutions in Military Affairs and Military Revolutions

Source: MacGregor Knox and Williamson Murray. The Dynamics of Military Revolution, 13002050. (London, England: Cambridge University Press, 2001), 13.

The United States military in the interwar period of 1919-39 provides a historical example of innovation in an environment—a war weary public and reduced defense spendingmuch like the contemporary one. ${ }^{32}$ There was a substantial call for isolationism, to avoid

${ }^{31}$ Knox and Murray. The Dynamics of Military Revolution, 1300-2050, 13.

${ }^{32}$ Allan R. Millet and Williamson Murray, Military Effectiveness in the Interwar Period 
international law, alliances and practices, and to establish a barrier between the United States and foreign wars. ${ }^{33}$ The military did not receive any strategic guidance from the White House to guide organization or innovation. The National Defense Authorization Act of 1920 provided an active Army strength of 280,000, about half of what the War Department proposed. Over the following three years, the Army shrunk to an end strength of 125,000, less than any other major power. The Army focused on the infantry, not developing tanks and combined arms warfare. The Navy focused on the battleship, at the expense of naval aviation, anti-submarine, and amphibious warfare. The Army Air Corps overemphasized bombing at the expense of close air support for ground forces. Coastal defense units had coordination issues, mostly the result of complex and ambiguous roles, as the responsibility and mission were divided among the services. Despite these challenges, the military was still able to acquire key capabilities that enabled victory in World War II—the B17 bomber, 105mm howitzer, the M1 rifle, radar and sonar.

In his book Strategy: The Logic of War and Peace, Edward Luttwak presents strategy as a paradox and a dialectic of options applied in context and execution instead of an analysis of ends, ways and means. ${ }^{34}$ In other words, one prepares for war by building up a capability; one's enemy will see that as strength and deliberately try to circumvent it. This logic illuminates that the Chinese weapons technologies are attempting to negate the strengths of the US Navy and Air Force. The best avenue of attack is likely to be the most defended by the enemy therefore the most difficult avenue of attack may be better-which posits the need to defend current American

(Boston, MA: Unwin Hyman, 1988), 70.

${ }^{33}$ Ibid., 71.

${ }^{34}$ Edward N. Luttwak, Strategy: The Logic of War and Peace (Cambridge, MA: Harvard University Press, 1987), 1-17. 
intermediate staging bases such as Guam to maintain strategic agility at the end of extended lines of communication. ${ }^{35}$

Accordingly, an additional phenomenon noted is that technologically and numerically superior armed forces tend to take linear actions according to their "mistaken expectations of their own vast inherent superiority....without a sufficient effort to surprise the enemy by suitably paradoxical conduct." ${ }^{36}$ This "strategic paradox" infers the need to have complementary capabilities across domains because threat nations will attempt to defeat critical capabilities housed in the Navy and Air Force that enable access into a JOA. Luttwak states that there is a “technical level” of war which impacts tactical success. He uses the contemporary example of technologically superior tanks destroyed by low cost high technology anti- tank missiles. This is analogous to a low cost ASM destroying a high cost and technologically superior naval vessel in a future battle.

In Pure Strategy, Dr. Everett Dolman writes that strategy is about maintaining a position of continuous advantage since strategy can never lead to conclusion. ${ }^{37}$ Strategy has no endstate, it is a continuous cycle of moves and counter moves by allies and opponents. Chaos and complexity’s impact on military strategy infers that strategy is now about change and adaptation to meet the challenges of unexpected emergent events of the positive and negative feedback loop. ${ }^{38}$ The strategist must increase options to provide additional alternatives that achieve tactical

${ }^{35}$ Ibid.

${ }^{36}$ Ibid., 16.

${ }^{37}$ Everett C. Dolman, Pure Strategy: Power and Principle in the Space and Information Age (New York, NY: Frank Cass, 2005), 4.

${ }^{38}$ Robert Jervis, System Effects: Complexity in Social and Political Life (Cambridge, MA: Cambridge University Press, 1997), 126. 
victory and strategic continuing advantage. ${ }^{39}$ Dolman believes that the opponent is going to attempt to destroy the friendly force's strongest options so the strategist must create and preserve them. Dolman states that the strategist seeks to increase choices for the opponent and by doing this, he increases his own power. This provides additional reinforcement of the need for complementary capabilities in order to maintain access into a JOA.

Within this construct, he urges the military to “maximize nodes” and utilizes game theory to expand the idea. In short, the more coins you flip (more complementary capabilities), the less predictable the outcome will be as the number of turns increases. These ideas have direct implications for complementary ASM capability because "strategists seek to increase available options by manipulating structure and context, and in this way dictate the terms of the conflict." 40 The ability to maximize nodes increases the operational and strategic agility needed to maintain a position of continuing advantage. Scenario planning exercises such as the US military's Unified Quest examine concepts and shortfalls to maintain this position.

The Defense Department and private industry use scenario planning to examine possible futures, identify potential capabilities in the face of uncertainty, and to prepare for and exploit emergent events in a complex environment. ${ }^{41}$ Scenario planning is not a forecast; it is an answer to "what can conceivably happen” or "what would happen if...?” This process enables risk management because it reveals risk. ${ }^{42}$ "Imagining defeat" is a method in scenario planning to

${ }^{39}$ Ibid., 9.

${ }^{40}$ Ibid., 43.

${ }^{41}$ Bill Ralston and Ian Wilson, The Scenario Planning Handbook: Developing Strategies In Uncertain Times (Mason, OH: South-Western, 2006), 1.

${ }^{42}$ Mats Lindgren and Hans Banhold, Scenario Planning: The Link Between Future and Strategy (Baskingstoke, Hampshire: Palgrave Macmillan, 2003), 22. 
process trace the causes of failure to guide innovations. The Department of Defense uses its annual Unified Quest scenario planning exercise to identify gaps and guide private industry in developing processes and technologies to increase this future agility. Organizations such as the National Intelligence Council utilize the process to provide a framework to think about the future by identifying critical trends, discontinuities, megatrends, game changes, and critical variables that could change the manner in which nations view the way they fight or change their strategic context for the application of the elements of national power. ${ }^{43}$

The School of Advanced Military Studies’ Strategic Initiatives Group utilized scenario planning to develop their “Imagining Defeat in 2030: Mitigating Strategic Surprise to the US Army by Envisioning the Worst” white paper. In their scenario, a US military organization conducting stability operations in Indonesia was at risk of being overrun by a Chinese amphibious invasion force. They were unable to receive air and/or naval support because of a higher priority conflict in the Straits of Hormuz. Notable implications of their study included that "developing agile institutions will be more important than predicting future threats" and that "sustaining overmatch in 2030 will demand a tighter innovation cycle.”44 The results of this study and the annual Unified Quest exercise imply the need for cross-domain complementary capabilities that support strengths and compensate for the weaknesses of others. Recent history has demonstrated that a trend for littoral combat includes the usage of ASMs against Naval and merchant vessels. Scenario planning is a method to develop capabilities that the United States can utilize to develop

${ }^{43}$ Office of the Director of National Intelligence, Global Trends 2030: Alternative Worlds, accessed July 10, 2014, http://www.dni.gov/index.php/about/organization/nationalintelligence-council-global-trends.

${ }^{44}$ Strategic Initiatives Group, Imagining Defeat in 2030: Mitigating Strategic Surprise to the US Army by Envisioning the Worst (Fort Leavenworth, KS: School of Advanced Military, 2014), 2. 
the agility noted in the Lyceum white paper to both defend ISBs and enable access into contested JOAs.

Wayne Hughes in Fleet Tactics and Coastal Combat details the record of missile combat between fleets since World War II. Every case of such combat occurred in littoral waters. ${ }^{45}$ The first cruise missile attack occurred during the 1967 Arab-Israeli War when the Israeli destroyer Eilat sank from an Egyptian barrage of four Soviet produced Styx missiles. In the 1971 IndoPakistan War, the Indian military utilized nine Styx with much success against Pakistani warships and merchant vessels. In the 1973 Arab-Israeli War, Israel employed 101 Styx and Gabriel with devastating effects against Syrian and Egyptian vessels. During the 1982 Falklands War, and for the first time in combat, both air and ground launched ASMs were employed. Iraq fired ASMs against the USS Stark in 1987, during the 1988 “Tanker War,” and during the opening stages of the Gulf War against the United States in February 1991. ${ }^{46}$ In total, Hughes documents 155 ASM attacks since the late 1960s_ - opening up "missiles and missile warfare as the dominant modern warfare at sea.” ${ }^{47}$ The successes of ASMs against naval vessels in littoral combat lends further credence to the need for the Army to acquire and field a land based system to enable access into a JOA during potential ASM attacks against the United States Navy.

This literature review examined RMA literature that demonstrated the theoretical framework of this monograph and a historical example of innovation in a fiscally constrained environment. Scenario planning literature demonstrated the manner in which the US military forecasts futures and potential gaps in capabilities. The conclusions of this literature review revolve around the following variables: successful military innovation utilizing the elements of

${ }^{45}$ Wayne P. Hughes, Fleet Tactics and Coastal Combat (Annapolis, MD: Naval Institute Press, 2000), 151.
46 Ibid., 152.
${ }^{47}$ Ibid., 153. 
RMA including technology, doctrine, and organizations and how innovation through these variables impact strategic and operational agility in the complex operating environment.

\section{Research Methodology}

This monograph is presented with structured focused, process tracing qualitative case studies. These case studies will examine the elements of a successful RMA, Luttwak’s strategic paradox, Dolman's views of strategy, and relevant elements of scenario planning literature. The first is a positive case study in which the United States was able to successfully innovate using lessons learned from the 1973 Arab-Israeli War, theoretical foundation of Soviet Deep Operations Theory, and future scenario planning at Forts Leavenworth and Sill to develop the Army Tactical Missile System (ATACMS) in support of AirLand Battle doctrine. The second case study is a negative case study in which the United States Army failed to innovate from the lessons learned in the Falklands War and chose not to develop complimentary cross-domain ASM capabilities that would enhance operational and strategic agility. The China threat scenario section will explore innovation using future scenario planning 


\section{Case Study I}

\section{Arab-Israeli War and the Army Tactical Missile System (ATACMS): Successful Innovation through Complementary Cross-Domain Capabilities}

To look back over that decade (1970s) is to be struck by the sluggish national awareness of the massive buildup of Soviet arms and the delayed political response to the Soviets' increasingly bold power moves directly and by Cuban proxy, in Africa, the Middle East, and Latin America.

-John L. Romjue, From Active Defense to AirLand

Battle: The Development of Army Doctrine 1973-1982

Revolutions in Military Affairs happen as an outcome of innovations directed at specific threats and problem sets. ${ }^{48}$ Nations develop doctrine to meet national requirements and the challenges of the operating environment utilizing scenario-planning exercises such as Unified Quest and the Fort Leavenworth based Lyceum. ${ }^{49}$ It is a look back at history, the operational environment, and future requirements. Doctrine is an outcome of the interplay between theory and history. Theory and history informed the development of the ATACMS missile. The missile complemented Air Force munitions in support of AirLand Battle doctrine. It is a successful example of innovation in support of doctrinal concepts in an interwar period and provided an additional flexible deterrent option to the combatant commander. This paper examines key elements of RMA literature, including the challenges of developing doctrine, organizations, and technologies that enable operational and strategic agility.

General William E. Depuy took command of the United States Training and Doctrine Command (TRADOC) in July 1973 and fastidiously worked to break the acquisitions morass of

${ }^{48}$ Knox and Murray, The Dynamics of Military Revolution, 192.

${ }^{49}$ ADRP 3-0 presents the Joint Publication 3-0 definition of Operational Environment as a "composite of the conditions, circumstances, and influences that affect the employment of capabilities and bear on the decisions of the commander." Army Doctrine Publication (ADP) 3-0, Unified Land Operations (Washington, DC: Government Printing Office, 2012), 2. 
the Vietnam War. He wanted to develop the parameters of the next generation of innovative weapons and technology and utilized the lessons learned from the October 1973 Arab-Israeli War as a lens for procurement. ${ }^{50}$ TRADOC recognized the increasing lethality of weapons systems, especially in the close fight. The central idea in the development of this weapons system was to attack the second echelon forces of the Soviet Union in depth to disrupt operational maneuver and prevent the envelopment of North Atlantic Treaty Organization (NATO) forces by a numerically superior force in any contingency on the battlefields of Western Europe. This recognition of the need to develop technologies in support of new doctrine was the first step in this example of successful innovation and has parallels to current Defense Strategy, Doctrine, and Concept documents that have emerged since 2012.

TRADOC developed the “Division 86” scenario planning group in October 1978 to develop concepts for how every echelon of the Army would fight on the future battlefield. The task of developing concepts to operate in depth in order to combat the overwhelming size and firepower of the Warsaw Pact Armies fell to the Field Artillery School at Fort Sill, Oklahoma. ${ }^{51}$ The development of AirLand battle doctrine in the late 1970s by TRADOC was a RMA that recognized the merit of Deep Operations theory advocated by Marshal Mikhail N. Tukhachevsky of the Soviet General Staff School in early $20^{\text {th }}$ century and its applicability in a potential conflict with the Soviet Union by targeting second and third echelons of the enemy force. ${ }^{52}$ The writers of

${ }^{50}$ John L. Romjue, From Active Defense to AirLand Battle: The Development of Army Doctrine 1973-1982, United States Training and Doctrine Command (Washington, DC: Government Printing Office, 1984), 2.

${ }^{51}$ Ibid., 32.

${ }^{52}$ For further reading on the history of Soviet Deep Operations Theory see Jacob Kipp’s "The Origins of Soviet Operational Art 1917-1936 in Michael D. Krause and R. Cody Phipps, ed., "Historical Perspectives on Operational Art," (Washington, DC: CMH, 2005), 189-208 \& 291-308 or Condoleezza Rice’s “The Making of Soviet Strategy,” in Peter Pared, ed, Makers of Modern Strategy: From Machiavelli to the Nuclear Age, 2d ed. (Princeton, NJ: Princeton 
Field Manual 100-5: AirLand Battle recognized that the United States needed several complementary weapons systems in order to implement this new doctrine and execute deep operations. The Division 86 concept fed subsequent AirLand battle symposiums held between General Officers of the Army and Air Force and spawned the Corps 86 scenario-planning group that outlined opportunities for U.S. forces to go on the offensive.

One outcome of these meetings was the realization that the Field Artillery could do little outside of the employment of tactical nuclear weapons to counter second echelon forces of the Warsaw Pact armies. The employment of tactical nuclear weapons by the United States was hampered by clearance time for their use from the national command authority—by the time approval came the advantage of use would be lost. ${ }^{53}$ An additional disadvantage was the potential of escalatory weapons employment that could lead to nuclear holocaust. ${ }^{54}$ The Army needed to innovate to meet the challenges posed in this operating environment.

The Corps 86 scenario planning meetings in 1980 at the Combined Arms Center at Fort Leavenworth defined the framework of the "deep battle area” beyond the forward line of troops (FLOT). The area of influence would extend out to 150 kilometers and the area of interest would extend 300 kilometers beyond the FLOT. This definition placed the onus on the Corps Commander to operate 72 hours beyond the FLOT in the area of interest and coordinate second echelon interdiction efforts utilizing airpower and tactical nuclear and chemical weapons. ${ }^{55}$

University Press, 1986), 648-76.

53 John L. Romjue, From Active Defense to AirLand Battle: The Development of Army Doctrine 1973-1982, United States Training and Doctrine Command (Washington, DC: Government Printing Office, 1984), 32.

${ }^{54}$ Boyd L. Dastrup, Modernizing the King of Battle 1973-1991, USAFACS Historical Monograph Series (Fort Sill, Oklahoma: Center of Military History, 2003), 14.

${ }^{55}$ Ibid., 52. 
Defining the deep battle area informed capabilities development between the Air Force and the Army and facilitated the development of complementary precision and strike munitions to target follow on echelon forces - an example of a successful RMA under Knox \& Murray’s “military revolution 5: nuclear weapons and ballistic missile delivery systems.”56

The Army Tactical Missile System (ATACMS) was born out of an innovative and integrated approach to fighting in an extended deep battlefield. Corps Commanders were charged with delaying and destroying follow on echelons utilizing a combination of conventional and nuclear systems employed by new sensors and surveillance systems. TRADOC closely examined the Israeli experience at the outset of the 1973 Yom Kippur War. Israel lost thirty-five aircraft to Egyptian integrated air defenses (IADs) in the first forty-eight hours of the conflict. Israel recognized that it needed a complementary capability to defeat the IADS and subsequently utilized multiple rocket launch (MRL) systems to effectively neutralize ground-based threats and achieve local air superiority—a historical example of cross domain synergy. ${ }^{57}$ TRADOC recognized the missile force relied on the aging Pershing II missile and that the Field Artillery did not have a mobile rocket launcher capable of providing the same level of fire support Israeli MRL systems did during the Yom Kippur War. TRADOC utilized the Israeli experience as a historical model for what the US military would encounter on a future battlefield in Western Europe, to inform doctrinal development, and to drive organizational and material development in support of their concepts.

Innovation difficulties in support of AirLand battle extended into private industry and in an inter-service rivalry. In 1977, the Defense Advanced Research Projects Agency (DARPA) requested that private industry design a weapon system with sufficient range to disrupt Soviet

\footnotetext{
${ }^{56}$ Knox and Murray, The Dynamics of Military Revolution, 1300-2050, 13.

${ }^{57}$ Dastrup, Modernizing the King of Battle 1973-1991, 11.
} 
second and third echelon forces and compensate for NATO's numerical inferiority. This project led to the Assault Breaker program that designed air-to-surface and surface-to-surface missiles to carry sub-munitions that destroyed enemy armored formations. The Air Force and the Army subsequently developed competing programs with divergent requirements. According to longtime Fort Sill Command Historian Dr. Boyd L. Dastrup, “the Army wanted a missile with sufficient propulsion for ground launch, and the Air Force desired a small missile that could be carried by a B-52." 58 The Department of Defense was wary of duplication and sought cost savings so it merged the Army’s Corps Support Weapons System Program (CSWS) and the Air Force's Conventional Standoff Weapon System Program. Although the Air Force and Army could not agree on a singular weapon system, the two services decided on separate but complementary capabilities that would target the second and third echelon problem set. The two services sought to divide battlefield responsibilities through the development of their complementary Joint Tactical Missile Systems (JTACMS) programs. The Army developed a short range and groundbased missile with terminally guided sub munitions that would target enemy formations that could immediately impact the close battle. The Air Force developed a long range, air-launched missile with terminally guided sub munitions that targeted enemy formations on a deeper time horizon. The point was clear-although the Army and the Air Force were unable to agree on the same munition, they both agreed that they would need complementary and overlapping capabilities to meet the challenges of the projected numerical inferiority of NATO forces in a battle against Warsaw Pact nations.

The development of the ATACMS missile is a successful example of innovation formed by an examination of historical battle, theory, and scenario planning. The Army and the Air Force

${ }^{58}$ Boyd L. Dastrup, US Army Field Artillery Center and School Annual Historical Review 1 January 1986 Through 31 December 1986 (Fort Sill, Oklahoma: Center of Military History, 1986), 77. 
were able to come to an agreement through the Assault Breaker program when both services realized that their capabilities complimented each other and enabled joint fires for decades to come. The United States did not realize the same lessons learned on complementary and overlapping capabilities after the 1982 Falklands War.

\section{Case Study II:}

\section{Falklands War: A Failure to Innovate with Complementary Cross- Domain Capabilities}

The 1982 Falklands War provides an example of a failure of the United States military to conduct cross-domain post conflict innovation in a similar manner as it had following the 1973 Arab-Israeli War. Only within the last two years has the military produced concept documents to direct capabilities that enable operational and strategic agility in an A2AD environment similar to what Generals Depuy and Starry accomplished in their time at TRADOC in the 1970s. The following case study provides a narrative on the Falklands War along with an examination of the United States’ failure to innovate in the key elements of RMA, including technology, organization, and doctrine, and an examination of China's successes in these same key elements.

In Deterrence, Lawrence Freedman stated that the Falklands War was a failure of the British to deter the Argentine occupation of the Falklands due to its small military footprint in the region, inability to convince international actors in its land claim, and its overall "halfheartedness of its effort."59 The Falklands provides the most recent example of a naval power attacking across an extended sea and air lanes of communication into a contested environment. The Chinese see this conflict as analogous to a cross-strait conflict over Taiwan. ${ }^{60}$ The 1982

${ }^{59}$ Thomas Freedman, Deterrence (Cambridge, MA: Polity Press, 2004), 117.

${ }^{60}$ Andrew Schobell David Lai and Roy Kamphausen, "Chinese Lessons From Other Peoples’ Wars,” Strategic Studies Institute (Carlisle, PA: US Army War College, 2011), 4. 
Falklands War traces its roots to competing claims for the islands between Britain and Argentina following Argentinean independence from Spain in 1820. Claims for territorial rights and for the rights of the island's inhabitants continued for the next 100 years, including lobbying to the United Nations by the Argentineans' in the years following World War II. Military conflict began when Argentina used force to reclaim South Georgia and the Falkland Islands.

Armed with a desire to avenge humiliation and protect its possessions, Britain attacked along a 7,000 nautical mile sea line of communication using a combined air, sea, and amphibious invasion force. ${ }^{61}$ Britain successfully defeated the Argentinean force on the islands utilizing complementary weapons systems and tactics to achieve joint synergy throughout the battle, including the usage of submarines to deny Argentinian Naval surface vessels access to the conflict. Contemporary Chinese analysts of the war criticized the Argentineans for not stockpiling more anti-ship missiles prior to the onset of the conflict and for not attempting to attack the severely extended British logistical line back to the Ascension Islands. ${ }^{62}$

A 1983 US Navy report re-affirmed its doctrine, technological, and armor advantage of the carrier fleet in comparison to the "light skinned" Royal Navy vessels. ${ }^{63}$ This report's findings on US Naval vessel survivability during an ASM attack is debatable in light of the results of an Iraqi attack using the same Exocet missiles on the USS Stark in $1987 .{ }^{64}$ The report advocated the continued development of Air Force and US Navy anti-ship missiles. Currently, the US Navy and

${ }^{61}$ Duncan Anderson, The Falklands War, 1982 (Oxford: Osprey, 2002), 21.

${ }^{62}$ Schobell, Lai and Kamphausen, Chinese Lessons From Other Peoples’ Wars, 78.

${ }^{63}$ US Department of the Navy, Lessons of the Falklands: Summary Report (Washington, DC: Government Printing Office, 1983), 3.

${ }^{64}$ US Department of the Defense, Formal Investigation Into the Circumstances Surrounding the Attack on the USS Stark on 17 May 1987, accessed July 30, 2014, http://www.jag.navy.mil/library/investigations/uss\%20stark\%20basic.pdf. 
Air Force do not possess conventional offensive and defensive measures with ranges that exceed Chinese missiles designed to prevent the two services from operating within $2000 \mathrm{~km}$ of the mainland. While the Air Force and Army developed complementary capabilities in support of AirLand Battle, the Air Force, Navy, and Army have not developed a complementary anti-ship missile capability that will enable access into a contested joint operations area (JOA).

The United States government has recently acknowledged the threat to its national interests that the A2AD problem set poses and has made steps to address it. Innovation to support A2AD environmental challenges had not adequately addressed the doctrinal, technological, and organizational advancements by China until the 2012 Defense Strategic Guidance (DSG). The DSG highlighted the threat by directing the military to project force despite A2AD threats and directed conceptual development in a manner to TRADOC and General Starry in the 1970s. ${ }^{65}$ Conceptual documents such as the Joint Operational Access Concept (JOAC) and Air-Sea Battle are directing capabilities in an attempt to inform the services and acquisition community on innovative complementary technologies needed to enable operational and strategic agility. The littoral combat ship (LCS) and the DARPA/Navy Air and Surface Launched Offensive AntiSurface Warfare program (OASuW) are recent examples of innovative technologies developed in support of the threat. The JOAC describes thirty critical capabilities that the Army needs to develop in order to be successful in an A2AD environment (see Appendix A). ISBs are critical-for sustaining US entry operations. China, applying lessons learned from the Falklands War and US operations in Afghanistan and Iraq, views the neutralization of American ISBs as a

${ }^{65}$ US Department of Defense, Sustaining U.S. Global Leadership: Priorities for $21^{\text {st }}$ Century Defense (Washington, DC: Government Printing Office, 2012), 4. 
critical to their counter-intervention strategy. ${ }^{66}$ The protection of key ISBs, including Guam, will be a critical part of any rebalance to the Pacific.

China continues to utilize the Falklands War as a case study to guide the technological innovation of their Second Artillery Corps. One of the only primary source English language articles written on Chinese Lessons Learned from the 1982 Falkland's War is Lyle Goldstein's China's Falklands Lessons. The author uses a quote from the PLA Navy Chief of Staff that states, "For the future of military theory, development of military units and of military equipment [the Falklands] war produced a deep influence." ${ }^{67}$ China has not fought a war since 1979 and the Falklands provides a case study on combined air, sea, and amphibious warfare for the development of policy, doctrine, and weapons innovation for any Taiwan contingency. Goldstein draws out the strongest lessons learned from the War-the usage of the Exocet anti-ship cruise missile against British naval targets and the failure to attack the British intermediate staging base in the Ascension Islands. An ASM is an asymmetric tactic that pits a low tech and low cost weapon system against a high tech and high cost vessel and in this case, the former, an anti-ship missile, caused severe damage to the latter, the HMS Sheffield and the merchant vessel Atlantic Conveyer.

Chinese Lessons From Other Peoples Wars is a 2011 publication from the Strategic Studies Institute (SSI), the National Bureau of Asian Research (NBR), and the United States Pacific Command (USPACOM), which examines the Chinese People’s Liberation Army’s (PLA) lessons learned from other nation's wars over the course of the last 30 years, including lessons learned from the 1982 Falkland-Malvinas War. The authors assert that conflict "remains to this

\footnotetext{
${ }^{66}$ Mulvenon and Finkelstein, China's Revolution in Doctrinal Affairs: Emerging Trends in the Operational Art of the Chinese People’s Liberation Army, 262. 761.

${ }^{67}$ Ding Yiping, Shijie Jaijun Shi, World Naval History (Beijing: Sea Tides Press, 2000),
} 
date the most classic case between two determined warring nations involving the use of sea, air, and ground forces, with long range expeditions and close engagements.”68 It details the policy, weapons procurement, and military doctrinal innovation that China subsequently adopted. The Chinese analyst noted that the British were able to deploy an integrated "protective bubble” of joint forces to deter attack. This bubble was then able to isolate the Argentinean military from mainland South America providing an effective "shield" against follow on forces. ${ }^{69}$ The Chinese noted the success of Argentinean diesel submarines in penetrating the British anti-ship warfare (ASW) screen and recently developed their own fleet. The Chinese look at the 8,000-mile supply line as a key “Achilles heel” that the Argentinean military never successfully exploited. Numerous Chinese writings note the importance of basing and access to the British success.

Chinese Lessons From Other Peoples Wars and Falklands Lessons posit many implications for US Army innovation in support of the Joint Operational Access Concept. Since the late 1990s, the military has observed the rise of Chinese A2AD capabilities in support of their counter-intervention strategy. The Army’s Role in Overcoming Anti-Access and Area Denial Challenges is a 2013 RAND Corporation report that reviews US operations since World War II and concludes that in most situations the United States employed a tailored joint, interagency, intergovernmental, and multinational approach to “diplomatic, geographic, and military A2AD challenges." ${ }^{70}$ It discusses the joint interdependence and synergies that are needed to overcome an opposed access environment that has dozens of A2AD threats. The Army's contribution to this fight, according to RAND, is four fold: (1) missile defense at Air Force bases, (2), ground maneuver units for base protection, (3) engineering and logistics support and, and (4) SEAD with

\footnotetext{
${ }^{68}$ Schobell, Lai and Kamphausen, Chinese Lessons From Other Peoples’ Wars, 11. ${ }^{69}$ Ibid., 85.

${ }^{70}$ John Gordon IV \& John Matsumura, The Army's Role in Overcoming Anti-Access and Area Denial Challenges (Santa Monica, CA: RAND Corporation, 2013), x.
} 
the Army Tactical Missile System (ATACMS). The Navy’s primary threat in this report is from anti- ship ballistic missiles (ASBMs). According to RAND, the Army's role in defeating the antiship ballistic missile threat is to forward deploy UAS and attack helicopters to destroy enemy craft operating in littoral regions; and forward deploy air defense assets to protect ships while they are conducting logistical resupply. ${ }^{71}$ Finally, the report discussed the long-range artillery capability gap in support of an attack against an opposed environment.

The failure of the United States military to successfully innovate cross- domain complementary capabilities in the aftermath of the Falklands War is traced to an organizational and cultural belief that the Falklands was an anomaly. The general belief in the 1980s was that a ground battle in Western Europe with the Soviet Union was the future and that lessons learned from the Falklands were primarily naval and air force related. Indeed, US Navy and Air Force documents demonstrated a level of organizational and technological over- confidence. They concluded that their equipment, tactics, and organizations would not have had the same battlefield challenges that the British did operating in what the United States now calls an A2AD environment. Unlike the aftermath of the Arab-Israeli War, TRADOC leadership did not take the steps that General Starry took in the mid-1970s to direct concept and technology development from observations of the Falklands. General Starry identified a capability gap and directed concepts and technological study to address it—-the Army of the 1980s did not.

Conversely, the Chinese experienced a similar capability crisis in light of the 1996 Taiwan Strait Crisis. Then-President Jiang Zemin directed concept and capability studies to counter the ability of nations to project power in their "near seas” after the United States sent two Carrier-battle groups into the region in response to Chinese missile tests directed at Taiwanese

${ }^{71}$ Ibid., 26. 
objections over the "One China” policy. ${ }^{72}$ This incident jump-started Chinese military

modernization and the development of complementary cross-domain A2AD capabilities,

especially in the Second Artillery Corps.

\section{Imagining the Future: A Counterfactual Examination of the Chinese A2AD Threat and Its Implications for a Land Based Anti-Ship Missile}

The modern U.S. Navy is a victim of outmoded nuclear-war thinking. To this day, most warships have little staying power. One or two hits with modern missiles such as Exocet or Harpoon will put most warships out of action...it is easy to show that the world's navies are in a new age in which anti-ship missiles are the most influential weapons shaping tactics.

-Wayne Hughes in Fleet Tactics and Coastal Combat

\section{Contextual Background}

Carl Von Clausewitz stated that war is "only a branch of political activity... that is in no sense autonomous." ${ }^{73}$ In this light, it is important to analyze the operating environment to highlight China's political, military, and economic aspiration in the western Pacific and potential implications for America's ability to project combat power into the region. China's national strategic goals are "perpetuating Chinese Communist Party (CCP) rule, sustaining economic growth and development, maintaining domestic and political stability, defending national sovereignty and territorial integrity, and securing China's status as a great power."74 China has pursued a national strategy of hard realpolitik with a tendency to favor offensive action. This

${ }^{72}$ Schobell, Lai and Kamphausen, Chinese Lessons From Other Peoples’ Wars, 222.

${ }^{73}$ Carl Von Clausewitz. On War, trans. Michael Howard, Peter Paret, and Bernard Brodie (Princeton, NJ: Princeton University Press, 1984), 605.

${ }^{74}$ US Department of Defense, Annual Report to Congress: Military and Security Developments Involving the People's Republic of China 2013 (Washington, DC: Government Printing Office), 15. 
view reflects their characterization of the world as adversarial and threatening and conflict as "zero sum, in which the application of violence is ultimately required to deal with threats."”5 Al Johnston, in “Cultural Realism and Strategy in Maoist China,” asserted that this reflects the axiom of quan bian, which advocates flexibility and an understanding of internal military abilities those of one's adversaries. If the balance is favorable, then one adopts offensive strategies; if they are less favorable then it is in China's best interest to buy time defensively until a balance shifts in their favor. ${ }^{76}$ Johnston draws from a quantitative study to show that the Peoples Republic of China (PRC) has had eleven foreign policy crises through 1985 and utilized violence to resolve eight of them (seventy-two percent). ${ }^{77}$ These conflicts disproportionately involved threats to Chinese territorial integrity, involving eighty- percent of all Chinese conflict over the same time period_-an ominous statistic in the light of ongoing Western Pacific territorial disputes over the last decade. ${ }^{78}$ In 2009, China submitted the so-called "nine-dash line map" to the United Nations (Figure 2 below), which asserted its claim for ninety percent of the South China Sea.

${ }^{75} \mathrm{Al}$ Johnston, “Cultural Realism and Strategy in Maoist China,” The Culture of National Security: Norms and Identity in World Politics (New York, NY: Columbia University Press, 1996), 251.

${ }^{76}$ Ibid.

77 Jonathan Wilkenfeld, Michael Brecher, and Sheila Rosen, Crisis in the Twentieth Century: Handbook on Foreign Policy Crisis (New York, NY: Pergamon, 1988), 161.

${ }^{78}$ Johnston, “Cultural Realism and Strategy in Maoist China,” 252. 


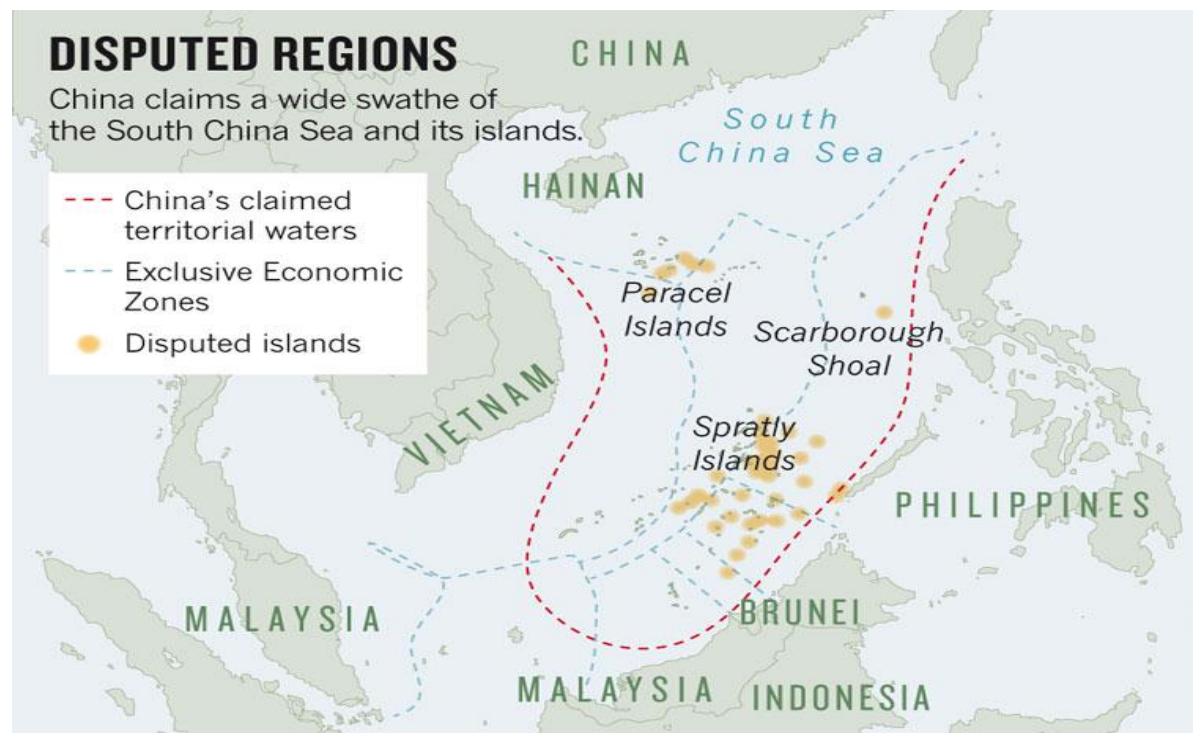

Figure 2. Graphical depiction of disputed South China Sea territory

Source: Council on Foreign Relations. South China Sea Tensions. Accessed on July 10, 2014, http://www.cfr.org

Some of the most contentious territorial disputes are in the South China Sea, including competing claims from the six major Southeast Asian nations over the Spratly Islands, Pratas Islands, Scarborough Shoal, Parcel Islands, and the Macclesfield Bank. China’s disputes trace to their desire to project power from the near seas (within the first island chain) to the far seas (beyond Japan, Taiwan, and the Straits of Malacca). China is attempting to create and enforce a naval policy that ensures freedom of action on the global commons and prevents any threat to their commerce by another nation dominating their sea lines of communication in the Western Pacific region- preventing an "economic hostage" situation. ${ }^{79}$

China is emerging from its self-proclaimed "century of humiliation" with a strong investment in their military and technology. From 2007 to 2012, the PLA Navy submarine and

\footnotetext{
${ }^{79}$ Ye Hailan, "Safe Seas," Beijing Review 52, no. 13 (April 2009): 10-11, accessed July
} 29, 2014, https://www. http://www.bjreview.com.cn/world/txt/2009-03/31/content_188746.html. 
combat readiness patrols increased six-fold, maintaining a near constant presence beyond their territorial waters. ${ }^{80}$ China's activity focuses on the Philippine Sea, a crucial area for any future conflict with the United States. ${ }^{81}$ They have introduced five new classes of nuclear and conventional submarines over a ten-year period. ${ }^{82}$ Reports starting in 2009 note China’s development of a "carrier killer" ballistic missile that can strike aircraft carriers at a distance of over 2,000 kilometers $(\mathrm{km})$, shaking the foundations of "unassailable U.S. Naval superiority in the pacific.”83 The Dong Feng-21C mobile launched missile reportedly has a range of 2,500 km, and its mobility makes targeting that much more challenging. China's counter intervention concept, as part of its Maoist doctrine of active defense, attempts to prevent an international force from interfering with their military operations beyond the first island chain. ${ }^{84}$ Some authors believe this strategy's goal is Chinese re-unification with Taiwan while others believe that

${ }^{80}$ Senate Committee on US-China Economic and Security Review Commission, China's Navy Extends its Reach to the Indian Ocean, $28^{\text {th }}$ Cong., $1^{\text {st }}$ sess., S. Rep., 1-9, accessed July 10, 2014, http://www.uscc.gov/Research/china's-navy-extends-its-combat-reach-indian-ocean.

${ }^{81}$ Senate Committee on US-China Economic and Security Review Commission, Hearing on PLA Modernization and its Implications for the Unites States, written testimony of Jesse Karotkin, ONI's Senior Intelligence Officer for China, $28^{\text {th }}$ Cong., $1^{\text {st }}$ sess., S. Rep, January 30 , 2014, accessed June 14, 2014, http://www.uscc.gov/Hearings/hearing-implications-china's-navalmodernization-united-states.

${ }^{82}$ Yoshihar and Holmes, Red Star Over The Pacific: China's Rise and the Challenge to U.S. Maritime Strategy, 2.

${ }^{83}$ Chandrashekar, Genesh, Raghunath, Nagappa, Ramani and Sundaresan, China's AntiShip Ballistic Missile Game Changer in the Pacific Ocean. International Strategic \& Security Studies Programme (ISSSP), accessed July 10, 2014, http://www.isssp.in/wpcontent/uploads/2013/01/2011-november-r-5-chinas-antiship-missile.

${ }^{84}$ Active defense strategy is rooted in the writings of Sun Tzu and was adopted by Mao Tse-Tung during the Chinese Civil War against Chian Kai-shek's Nationalist Army. It maintained that the Red Army was fighting from a position of disadvantage and would prepare conditions for a strategic counteroffensive that would decisively end the conflict. For further reading on active defense see Mao Zedong's Strategic Problems of China's Revolutionary War (Peking: Foreign Language Press, 1954). 
Taiwan is only a piece of a broader swing towards an Alfred Thayer Mahan view of the role of sea power. ${ }^{85}$ Regardless, the PLA Navy has become increasingly more aggressive in their patrolling and activity in the Yellow, South and East China Seas to project power on their disputed territorial claims. A March 2014 report from the United States-China Economic Security Review Commission entitled China's Navy Extends its Combat Reach to the Indian Ocean detailed a six-fold increase in PLA Naval combat patrols as far as the Philippine Sea in the years 2007-2014.

In his 2000 book Fleet Tactics and Coastal Combat, Wayne Hughes stated that American naval ships depend on open-ocean to effectively utilize their layered defense system of "combat air patrols, SAMSs, and hard-kill and soft-kill point defense" and that these tactics "lose their efficacy in littoral waters.” Hughes asserts that land based systems play a prominent role in littoral combat because of the range of the missiles will result in "naval battles that are a continuous string of operations that look like the stretched out Battle of the Atlantic than the short intense Battle of Midway." ${ }^{86}$ Within the framework outlined in the previous paragraphs, two scenarios are examined, a confrontation with China with and without a LASM and the implications for operational and strategic agility.

${ }^{85}$ China views their near seas in a similar manner to how Alfred Thayer Mahan viewed the isthmuses of Panama, Hawaii, and the Caribbean Sea as critical to the defense and economic prosperity of the United States in his writings in the $19^{\text {th }}$ century. For further reading on the aspirations of the Chinese Navy see Thomas Ehrhard and Rober Work in Range, Persistence, Stealth, and Networking: The Case for a Carrie-Based Unmanned Combat System (Washington, D.C: Center for Strategic and Budgetary Assessments, 200), 137-140 and Toshi Yoshihar and James R. Holmes, Red Star Over The Pacific: China's Rise and the Challenge to U.S. Maritime Strategy (Annapolis, MD: Naval Institute Press, 2010), 6-8.

${ }^{86}$ Wayne Hughes, Fleet Tactics and Coastal Combat (Naval Institute Press: Annapolis, MD, 2000), 149-168. 


\section{Analysis of the Threat}

The Red Star Over the Pacific examines Hughes' two broad categories of Chinese wartime contingencies. ${ }^{87}$ In scenario one, a confrontation happens in the open seas away from the protective umbrella of Chinese A2AD land based assets. In scenario two, a confrontation takes place within the umbrella (within 2,000km from the mainland). For the base of this analysis Scenario Two: "near shores" is utilized as China lacks the naval strength to engage the United States in a blue water battle outside of their land based A2AD capabilities. Hughes states that the PLA will utilize its extended land based weaponry to push the "Clausewitzian culminating point of attack” outward from Chinese coasts to "improve its prospects for denying the U.S. military access to important waters." ${ }^{88}$ The Chinese would then choose a blockade (through its counterintervention capabilities), an amphibious invasion, or a combination of both in an attempt to reunify Taiwan with China.

China — in light of the lessons learned they absorbed from US successes in the early stages of Operation's Iraqi Freedom, Enduring Freedom, Desert Storm and Allied Force—would utilize a combination of tactically offensive and strategically defensive pre-emptive strikes to minimize damage to its economic infrastructure and minimize social unrest in any attempt to reunify Taiwan with the mainland. ${ }^{89}$ China would then utilize a mixture of PLA Navy, amphibious attack, anti-satellite ballistic missiles, and ground based missiles from its Second Artillery Corps to attack US logistics, mission command nodes, and basing within its first two

${ }^{87}$ Yoshihar and Holmes, Red Star Over The Pacific: China's Rise and the Challenge to U.S. Maritime Strategy, 79.

${ }^{88}$ Ibid., 81.

${ }^{89}$ Mulvenon and Finkelstein, “China’s Revolution in Doctrinal Affairs: Emerging Trends in the Operational Art of the Chinese People’s Liberation Army,” 50. 
defensive rings in an attempt to deny foreign access, prevent a coherent regional response, and gain control over the Straits of Malacca. ${ }^{90}$ Japan, Guam, and US Naval assets within range are aggressively targeted—including the US Seventh Fleet and their assets in and around the Straits of Malacca and Luzon. Strategically, China attempts to degrade U.S. public support for entering the regional conflict, utilizing coercive deterrence through aggressive information operations. PRC ambassadors and senior military officials publicly state that any attempts by naval forces to enter a 1,000km exclusion zone from the coast of Taiwan will result in the destruction of the foreign fleet. These same ambassadors threaten an escalation beyond the current targets if India or any other US regional ally attempts to militarily intervene. The PLA Navy, utilizing its "four concentric ring approach” and recognizing the importance of Guam as the primary intermediate staging base for the United States in the region- would attempt to conduct an amphibious assault in order to seize the island and prevent its use for JSROI of US forces, but have only utilized missile attacks to this point. PLA officials determine that if the US carrier battle groups enter the exclusion zone then the amphibious assault would then commence on Guam, and privately note this to US officials in an attempt to limit military intervention.

The damage from the Chinese pre-emptive strike is unmistakable. Japan, deemed to be the key node for the United States in the Pacific, was aggressively targeted by the PLA. Dozens of ships from the Seventh Fleet are destroyed—dozens more damaged through both the missile impacts and subsequent fire damage. US basing across Japan was also targeted in an attempt to prevent its usage for command and control, logistics, and JSROI. US military casualties are highest in Okinawa, where over 1100 service men and women are killed. US basing in the Republic of Korea (ROK) and its political and military infrastructure were spared from PLA

${ }^{90}$ Ibid., 262. 
attack as an overture to the ROK government and in an attempt to gain greater influence with the civilian population, with which China is becoming increasingly popular.

American outrage across the continent is swift. Immediate overtures are made to the United Nations (UN) to authorize a resolution condemning the action and to authorize the use of force. Australia pledges basing and logistical support but is unwilling to directly attack the Chinese mainland. The international community is conscious of the economic interests of their respective nations and is also unwilling to commit to attacking China with lethal force. Japan engages numerous elements of the PLA Navy both with their surface ships and anti-ship missile assets. The South Korean government refuses direct military support as well, conscious of antiAmerican sentiment within their populace and because of a fear of the rising military sphere of influence of China.

The United States lacks the international coalition necessary to effectively conduct a decisive military campaign against the mainland. A limited objective campaign is selected, consisting of an economic blockade of China by denying traffic through the Straits of Malacca and Luzon, and shutting down both the oil and natural gas pipelines in Myanmar. An aggressive air and sea campaign against the PLA Navy and the Second Artillery Corps is conducted in an attempt to prevent an amphibious invasion of Taiwan. Elements of USPACOM, including two carrier battle groups position themselves just outside the range of the DF-21 awaiting word to continue from the National Command Authority (NCA). USPACOM Theater Fires Command begin targeting through joint and national sensors. LASMs are employed from MLRS and HIMARS targeting PLA Naval and merchant vessels in the region within the first twenty-four hours of the conflict allowing for both the Navy and the Air Force to conduct fixed wing attacks in an attempt to gain local air superiority and destroy key C2 nodes of the Second Artillery. The ability to defend key nodes to provide an entry point enables operational and strategic agility as US military leadership formulates further options and awaits orders from the NCA. 
Army Doctrinal Reference Publication 3-0 Unified Land Operations states that the Army’s expeditionary capability and their "campaign quality” allow it to "sustain operations as long as necessary,” and that Army forces “are organized, trained, and equipped for endurance.”91 What happens however, in a scenario where Naval and Air Force assets are unable to support an Army element conducting stability operations in Indonesia due to A2AD threats and a higher priority conflict in the Straits of Hormuz? A recent scenario-planning group at the School of Advanced Military Studies imagined US military defeat in the year 2030. ${ }^{92}$ A Chinese amphibious force attacked a contingent of US forces conducting stability operations in Indonesia and were unable to receive air and naval support due to competing requirements tied to a conflict with Iran. The Chinese amphibious assault force subsequently captured the US unit due to the lack of fire support caused by a combination of higher priority missions in the Middle East and A2AD threats in the Western Pacific.

This study demonstrates the need for innovation in support of existing defense concepts. This innovation includes a land based anti-ship missile that complements existing systems in support of Air-Sea Battle and the JOAC in a manner similar to Assault Breaker and the ATACMS missile supported AirLand Battle. There is no guarantee that the US will dominate the air and sea domains in any contingency with China due to the robustness of their cross-domain A2AD capabilities. A LASM is a comparatively low cost option that can complement air and sea systems, enable access, and provide a maneuverable low cost defensive flexible deterrent option.

${ }^{91}$ ADRP 3-0, 1-7.

${ }^{92}$ Strategic Initiatives Group, Imagining Defeat in 2030: Mitigating Strategic Surprise to the US Army by Envisioning the Worst (Fort Leavenworth, KS: School of Advanced Military Studies, 2014), 2. 


\section{What Kind of LASM}

A Land Based ASM supports the Ensure Forces Capable of Joint Entry Operations imperative from the 2012 Army Strategic Planning Guidance by providing a capability to “establish defensible positions." 93 It also supports central idea of the Joint Operational Access Concept (JOAC): cross-domain synergy ${ }^{94}$ This synergy advocates for complementary capabilities that "enhances the effectiveness and compensates for the vulnerabilities of the othersto establish superiority in some combination of domains that will provide the freedom of action required by the mission.” ${ }^{95}$ A LASM supports thirteen out of the thirty “critical capabilities” directed in the JOAC noted in Appendix A. There are competing opinions on the manner in which this complementary capability should be implemented into the US Army. The following is a synopsis of the range of implementation ideas:

\section{Option 1: Creating a Combined Arms Missile Force.}

In Why the U.S. Army Needs Missiles: A New Mission to Save the Service, the author advocates for the Army to acquire a land based anti-ship missile and withdraw from the Intermediate-Range Nuclear Forces Treaty which prohibits missile development in excess of 500 kilometers. He wants to create a separate missile regiment akin to the Chinese PLA Second Artillery Corps that has a combination of Field Artillery, Air Defense Artillery, and Space and Missile Defense Command assets and capabilities. Thomas argues that a revitalization of coastal

${ }^{93}$ US Department of Defense, 2012 Army Strategic Planning Guidance (Washington DC: Government Printing Office, 2012), 9.

${ }^{94}$ US Department of Defense, Joint Operational Access Concept, ii. ${ }^{95}$ Ibid. 
artillery would enable and preserve the viability of expeditionary ground forces. Thomas ends his article with the following assertion:

"Just as the battleship was gradually replaced by the aircraft carrier after World War II, in the coming era, the dominance of armored vehicles and mechanized infantry is likely to wane. Embracing this trend, rather than resisting it, is the best way for the army to ensure its continued relevance." 96

This argument continues in a July 2014 article. The article, entitled “China’s Missile Forces Are Growing: Is It Time to Modify the INF Treaty” cites China’s robust capabilities and press reports that Russia is developing a pair of missiles with ranges between 500 and 5000 kilometers. ${ }^{97}$ He states that forward-deployed missiles may provide a partial solution to the A2AD problem set in the Western Pacific. The author cites open source reports of Russian INF treaty violations by building new missiles that exceed the $500 \mathrm{~km}$ range limitation as justification for the United States to withdraw from the treaty to meet current military challenges. This option is the most costly of the options and would call for the largest deployed footprint of the three. It also would also call for new doctrine and headquarters organizations to integrate these capabilities with a combatant command. It also incurs the most risk, as the size of the footprint called for would enable targeting of these potentially large fixed sites by China's robust ballistic missile force.

${ }^{96}$ Jim Thomas,"Why the U.S. Army Needs Missiles," Foreign Affairs, accessed June 23, 2014, http://www.foreignaffairs.com/articles/139119/jim-thomas/why-the-us-army-needsmissiles.

${ }^{97}$ Evan B. Montgomery, “China’s Missile Forces Are Growing: Is It Time to Modify the INF Treaty?” The National Interest, accessed July 9, 2014, http://nationalinterest.org/feature/chinas-missile-forces-are-growing-it-time-modify-the-inf10791. 


\section{Option 2: Developing a LASM for the MLRS/HIMARS in a Field Artillery Brigade}

In this option, private industry develops a LASM for a MLRS and HIMARS with a range of 499km. Lockheed Martin successfully tested its Long Range Anti-Ship Missile (LARS) in 2013. This weapon system is a joint DARPA and US Navy funded program that has historical echoes of the aforementioned Assault Breaker program between the Army and Air Force. Named the Air and Surface Launched Offensive Anti-Surface Warfare Program, (OASuW), it provides the U.S. Air Force and Navy with a complementary capability to counter threats from A2AD doctrines. ${ }^{98}$ Fired from a US Air Force B-1B bomber, the missile scored a direct hit on a moving maritime target. It "navigated all planned waypoints receiving in-flight targeting updates from the weapons data link,” according to the Lockheed Martin press release. It is “armed with a 1,000pound penetrator and blast-fragmentation warhead, LARS employs a multi-mode sensor, weapons data link, and an enhanced digital anti-jam global positioning system to detect and destroy targets within a group of ships.” 99 This program could be adapted to a missile in a manner reminiscent of the Assault Breaker program for the MLRS and HIMARS systems. This option would be the least costly of the program since the technology for the missile has already been developed by Lockheed Martin but would need to be adapted for launch from existing launchers. Implementation of this option would be the easiest of the three because the munition is integrated into existing Field Artillery Brigades and their launchers. This option also incurs the least risk because it provides a scalable footprint that provides a Combatant Commander an offensive and defensive flexible deterrent option.

98 Zachary Keck, “US Tests New Stealthy Long Range Anti Ship Missile,” The Diplomat. (November 15, 2013), accessed June 23, 2014, http://thediplomat.com/2013/11/us-tests-newstealthy-long-range-anti-ship-missile.

${ }^{99}$ Lockheed Martin, “Lockheed Martin Conducts Second Successful LARS Flight Test. (November 14, 2013),” accessed June 23, 2014, http://www.lockheedmartin.com/us/news/pressreleases/2013/november/mfc-111413. 


\section{Option 3: Purchasing Commercial Solution}

The 2012 RAND study entitled “Employing Land-Based Anti-Ship Missiles in the Western Pacific" advocate for a commercial off the shelf purchase of the capability versus a munition developed for the MLRS and HIMARS or a new missile force as advocated in Option 1 by Thomas. The authors note a large number of potential missile deployment locations along the First Island Chain. Also, the numbers of systems that the authors advocate deploying supports their “credible deterrence” argument.

Their study is a RAND Arroyo Center project entitled "Preserving Army Capabilities in a Time of Downsizing,” to aid the U.S. Army’s Office of the Deputy Chief of Staff for Programs (G-8) in considering future capabilities for the Army. ${ }^{100}$ Its stated purpose was to "put forward a concept for how land forces could play a significant role in a conflict with China in the U.S. Pacific Command area of operations should Chinese aggression threaten U.S. allies or interests” and to present ideas on how to deter a conflict in the region through the introduction of new capabilities. ${ }^{101}$ It provides context for the United States' "rebalance to the Pacific" due to its economic and security interests in the region, including the Western Pacific, East and South China Seas, and the Indian Ocean. The report details the growing body of literature since the turn of the century on concerns about the rise of the Chinese military and their potential ability to impede American interests in the region and the broader global commons through a combination of joint-force capabilities, including anti-access weapons.

The authors assert that a LASM could be scalable option in the Pacific to enhance existing security agreements with partner nations, interdict foreign naval assets, or help create a

${ }^{100}$ Kelly, Atler, Nichols, and Thrall, Employing Land-Based Anti-Ship Missiles in the Western Pacific, iii.

${ }^{101}$ Ibid. 
"far blockade" to preserve economic freedom of movement in the contested waterways or prevent Chinese naval freedom of movement in a time of war. ${ }^{102}$ This option is in the middle for cost because of the organizational structure the Army would need to create to sustain a new foreign commercial asset integrated into its ranks. Developing targeting interoperability with existing US joint sensors will be an additional costly challenge. This option incurs the least operational risk because of the wide distribution of the system across that western pacific that the authors advocate for. It incurs the most strategic risk due to potential Chinese and Russian reactions due to the wide geographical deployment of these systems in manner analogous to Russian objections over U.S. missile defense in Europe.

\section{Potential Chinese Reaction}

There are numerous potential reactions and disadvantages of deploying this system in a permanent or semi-permanent basis in the Western Pacific. China has noted that the deployment of a LASM is confirmation of United States intention to create a "far blockade" for the PLA Navy within the first island chain. A LASM will almost certainly raise military and diplomatic tensions with China for both the United States and for TSCP partnered nations that choose to house the capability in a permanent or rotational basis. These tensions may bear out in the Philippine Sea. From 2007 to 2012, the PLA Navy submarine and combat readiness patrols increased six-fold, maintaining a near constant presence beyond their territorial waters. ${ }^{103}$ This activity is focused on the Philippine Sea, a crucial area for the Chinese in the event of conflict with the United States. A combination of increasing PLA Navy modernization and LASM

102 Ibid., xii.

${ }^{103}$ U.S-China Economic and Security Review Commission, “China’s Navy Extends its Combat Reach to the Indian Ocean,” 9. 
deployment could cause limited pre-emptive strikes against fixed basing targets to protect their maritime claims. ${ }^{104}$ This naval presence increases the potential for miscalculation due to the militarization of the sea reminiscent of the numerous incidents at the disputed Northern Limit Line (NLL) between North and South Korea.

The signaling of the United States' acquisition of a LASM may increase China’s military and diplomatic efforts to secure basing in the Straits of Malacca for their growing blue water Navy. Basing and logistical support would enable the PLA Navy in their attempts to protect their commercial shipping as it is transported through the Indian Ocean and through the Malaccan Strait. Over 80 percent of China's oil and gas imports are transported through these Straits. China has explored numerous options over the course of the last twenty years to circumvent the Straits of Malacca that are currently patrolled by both India and the United States. These include an “Asian Panama Canal” through Kra Isthmus in Thailand and developing an oil pipeline through Myanmar. Over the course of the last year a natural gas pipeline that carries 12 billion cubic meters per day opened and oil pipeline is expected to go on line by the end of 2014.

The permanent deployment of a LASM beyond Guam may inhibit the flexibility that the system would provide as a response option for a Combatant Commander. The rotational deployment demonstrates of US resolve to protect its interests in the region while not incurring additional risk from a fixed site. Permanent basing in a fixed site within the First Island Chain would enable targeting by China’s robust ballistic missile capability housed in its Second Artillery Corps. On the other hand, a rotational usage of this munition infers the need for numerous ammunition storage points (ASP) that have the necessary protection to withstand a

${ }^{104}$ U.S.-China Economic and Security Review Commission, Hearing on PLA Modernization and its Implications for the Unites States, written testimony of Jesse Karotkin, 4. 
ballistic missile barrage. Forward staging of ammunition is necessary because of its size and weight and would provide a large stationary target for China's ballistic missile force.

\section{Conclusions and Recommendations}

Relentless concentration on intelligently reshaping doctrinal concepts, on the analysis of experimentation aimed at solving specific identifiable problems....could indeed pay the massive dividend of a further American revolution or revolutions in military affairs.

-MacGregor Knox and William Murray in The

Dynamics of Military Revolution, 1300-2050

The goal of this study was to determine if there is a need for the United States Army to acquire of a land based anti-ship missile (LASM) as a complementary capability to US Air Force and Navy ASMs, utilizing the key elements of RMA literature as a theoretical basis for innovation. A LASM is not a technological innovation that will solve complexities of an A2AD environment. It does however, provide the National Command Authority a defensive flexible deterrent option and a weapons system that can defend disputed territory in partnered nations and intermediate staging bases. It provides a complementary capability that supports both Ashby’s Law of Requisite Variety and Dorner's efficiency diversity. ${ }^{105}$ Ashby’s Law of Requisite Variety states "only variety can destroy variety." ${ }^{106}$ It states that in order for an entity to be adaptive, the entity must match the variety imposed by the constraining environment. China has robust A2AD

${ }^{105}$ Dorner states that efficiency diversity is a capability or situation that “offers many different possibilities (diversity) for actions that have a high probability of success (efficiency). From Deitrich Dorner, The Logic of Failure: Recognizing and Avoiding Error in Complex Situations (Perseus Books Group: Cambridge, MA, 1996), 53-54.

${ }^{106}$ Max Boisot and Bill Mckelvey. "Integrating Modernist and Postmodernist Perspectives on Organizations: A Complexity Science Bridge," Academy of Management Review 35, no. 3: 415-43, Business Source Complete, accessed August 15, 2014, http://www. www.billmckelvey.org/-0-Pubs\%20to\%20be\%20added\%20as\%20Hot-Links. 
capabilities across all five domains that may constrain America's ability to gain access in the global commons. A LASM supports this theoretical concept.

An analysis of existing Army and Joint Service doctrine revealed no major doctrinal changes with the development and employment of a LASM in a Field Artillery Brigade. ${ }^{107}$ The Battlefield Command Detachment has the necessary organizational structure and multi-service personnel to aid in the clearance of fires for a LASM. The Field Artillery Brigade maintains an air defense airspace management element that has the necessary equipment to receive the joint air picture and coordinate directly with the Battlefield Coordination Detachment. ATP 3-60.1 MultiService Tactics, Techniques, and Procedures for Dynamic Targeting would need an update with the clearance of fires procedure for the employment of this munition. ATP 3-09.60 Techniques for Multiple Launch Rocket System (MLRS) and High Mobility Artillery Rocket System (HIMARS) Operations sets forth the doctrinal organization, equipment, mission command, operations, and techniques for these systems. The manual details the myriad of missions MLRS and HIMARS are capable of, from counterfire to "attacking operational targets for the division, corps, Marine air ground task force, or joint task force commander and in support of theater missile defense.”108 This manual would need an update accounting for the deployment structure of this capability including the necessary logistics, signal, target acquisition, mission command, and air and missile defense (AMD) support for deployment.

107 The review included ATP 3-09.24 Techniques for the Fires Brigade, ATP 3-60.1 Multi-Service Tactics, Techniques, and Procedures for Dynamic Targeting, ATTP 3-09.13 The Battlefield Command Detachment, ATP 3-09.60 Techniques for Multiple Launch Rocket System (MLRS) and High Mobility Artillery Rocket System (HIMARS) Operations, FM 3-09.12 Tactics, Techniques, and Procedures for Field Artillery Target Acquisition.

108 Army Techniques Publication (ATP) 3-09.60, Techniques for Multiple Launch Rocket System (MLRS) and High Mobility Artillery Rocket System (HIMARS) Operations (Washington, DC: Government Printing Office, 2014), 2-1. 


\section{A 2011 Army Capabilities Integration Center (ARCIC) and Mission Command Battle}

Lab (MCBL) entitled “Gain and Maintain Operational Access Event Report” outlined the need to enhance targeting and sensor fusion of "space based assets, UAS, and indirect fire sensors" and the need for further study on Field Artillery Brigade scalable early entry force packages that can enable joint targeting. ${ }^{109}$ This gap analysis highlighted the need to synchronize offensive and defensive fires with an emphasis on Joint Interagency, Intergovernmental, and Multinational (JIIM) interoperability. A realistic multi-service training scenario is needed that encompasses the clearance and employment of the munition on a seaborne target at a coastal training center such as the Pohakuloa Training Center (PTA) in Hawaii. Live fire training at home station with a LASM munition would be challenging due to airspace, the lack of $499 \mathrm{~km}$ missile training ranges, and realistic clearance of fires that account for the land, air, and sea domains and the appropriate clearance authority.

This monograph demonstrated that there are great advantages for the Army to develop a complementary anti-ship missile capability to Air Force and Naval capabilities to support the cross domain synergy that will provide the necessary freedom of action required in an A2AD environment. The development of AirLand Battle doctrine posed serious problems for the Field Artillery because it did not have the ability to engage Soviet first and second echelon forces simultaneously. ${ }^{110}$ The development of the of the Multiple Rocket Launch System (MLRS) and the ATACMS missile in the 1980s were a recognition of the interplay between theory (Soviet Deep Battle), history (successful employment of Israeli MRLs during the 1973 Arab-Israeli War) and doctrine (AirLand Battle), and a successful of example of innovation under the key elements

${ }^{109}$ US Department of Defense, Gain and Maintain Operational Access Event Report. (Fort Leavenworth, KS: Mission Command Battle Lab. 2012), G-5.

${ }^{110}$ Dastrup, Modernizing the King of Battle 1973-1991, 14. 
of RMA literature. The complementary capability and joint synergy that the MLRS and ATACMS enabled between the Air Force and the United States Army enabled operational and strategic agility in Operation Desert Storm and Operation Iraqi Freedom I through their tactical and operational successes. ${ }^{111}$

The 1982 Falklands War provides a contemporary example of a failure to innovate to strengthen operational and strategic agility by developing complementary capabilities to maintain a position of continuing advantage in an $\mathrm{A} 2 \mathrm{AD}$ environment. There are many lessons from this conflict including: (1) the effectiveness of relatively low cost A2AD technologies including ASMs against high cost/high technology systems; (2) the failure to target intermediate staging bases and long SLOCs to deny access into a JOA; and (3) the effectiveness of submarine warfare to deny adversarial Navy surface vessels the ability to enter the JOA. The Chinese People’s Liberation Army extensively mined this conflict for lessons learned as they see this as a mirror example of cross straight battle over Taiwan or other claimed Chinese territories. The Chinese noted the successes of Argentinean anti-ship missiles against the superior force of the British Royal Navy in their observations of the War. The Chinese were sharply critical of the failure of the Argentinean military to attack the perceived “Achilles Heel” of the British military—-their 7,000 nautical mile line of communication from the Falklands to the United Kingdom. The PLA has developed complementary capabilities with land, air, and sea based anti-ship missiles to enable joint synergy that supports their counter intervention strategy. To date, the United States military has not developed a Land Based Anti-Ship Missile that can enable that same synergy, protect intermediate staging bases from seaborne attack, and help protect United States freedom of action on the global commons. The United States has not had to face an adversary that was

111 Theodore J. Janosko \& Robert G. Cheatham, Jr, The Sound of Thunder: VCA in Operation Iraqi Freedom, Field Artillery Magazine, accessed August 8, 2014, http://www. http://www.highbeam.com/doc/1G1-110732260.html. 
able to threaten its access into a JOA. The statistics of ASM employment in the last forty years of conflict noted in Fleet Tactics provide a window into littoral combat that demonstrates that ASMs will be a prevalent part of joint combat and defense of key nodes. The development and deployment of a Field Artillery Brigade headquarters with joint sensor architecture and MLRS equipped with a Land Based Anti-Ship Missile provides a scalable offensive and defensive option to deter PLA Naval aggression in the region and provide measure of A2AD parity that would enable the protection of US military, economic, and diplomatic interests in the region.

\section{Recommendations}

The recommended innovation solution is Option 2: Developing a LASM for the MLRS/HIMARS in existing Field Artillery Brigades because of the (1) already established HQ structure and launchers, (2) the maturity of the DARPA/Lockheed Martin program, and (3) the scalability of the deployment of the asset. This LASM should be based off of DARPA and Lockheed Martin ASM technology, possess a 499 kilometer range, and be interoperable with the M2070A1 Multiple Launch Rocket System (MLRS) and M142 High Mobility Rocket System (HIMARS). This capability should be permanently deployed in support of Guam and rotate into the western Pacific as part of Pacific Pathways and the Theater Security Cooperation Programs (TSCP) to ensure naval parity in the Straits of Malacca, and to protect key ISB and the free flow of commerce in the region. The deployment of this capability as a scalable deterrent option in support of a Combatant Commander provides an additional complementary capability in contested zones and littorals to protect shipping lanes, sea lines of communication, American commerce, and intermediate staging bases- a $21^{\text {st }}$ Century deployable coastal field artillery. This capability would network existing joint and national targeting platforms through forward based combined tactical operations centers and fire direction centers and aid in the defense of ISBs, partner nation's interests, and provide a deterrent to future PLA naval aggression in the South China Sea. 
Further study by the Program Executive Office- Missiles and Space (PEO-MS), through coordination and approval with the Army Acquisition Executive and Defense Acquisition Executive, should examine the budgetary feasibility of building a new LASM program. Augmenting the existing DARPA/Lockheed Martin Offensive Anti-Surface Warfare (OASuW) program constitutes a recommended alternative. The Army G8 should direct Lockheed Martin’s LRASM programs to adapt their already developed LARS and LARS Boosted Test Vehicle (BTV) technology to a land based anti-ship missile capable of striking a target at $499 \mathrm{~km}$ from a MLRS or HIMARS in an electronic warfare environment. The synchronization of five-domain joint targeting and joint fires through a Theater Fires Command in an A2AD environment is a critical area of recommended research. Finally, research should examine the United States’ withdrawal from the 1988 Intermediate Missile Force Treaty (IMF) because of alleged violations by Russia. Withdrawal would enable a greater defensive deterrence and a longer range (greater than $499 \mathrm{~km}$ ) missile. 


\section{Appendix A: How a LASM Supports Critical Capabilities Directed in the JOAC}

Fires

- JOA-009. The ability to locate, target, and suppress or neutralize hostile antiaccess and area-denial capabilities in complex terrain with the necessary range, precision, responsiveness and reversible and permanent effects while limiting collateral damage. Deploy MLRS and/or HIMARS with a Field Artillery Brigade headquarters package to partnered Western Pacific nations utilizing existing joint targeting sensors and a LASM munition to deter PLA naval aggression.

- JOA-010. The ability to leverage cross-domain cueing to detect and engage in-depth to delay, disrupt or destroy enemy systems. Same as above.

- JOA-012. The ability to interdict enemy forces and materiel deploying to an operational area. The development and deployment of this capability provides a scalable defensive/offensive option to protect sea lines of communication and intermediate staging bases from naval and amphibious threats.

Movement and Maneuver

- JOA-016. The ability to conduct forcible entry operations, from raids and other limited-objective operations to the initiation of sustained land operations. Supports central idea of "Gaining and Maintaining Access: An Army-Marine Corps Concept” by countering the effects of adversary actions against air and sea domains. Also supports central tenets of Air-Sea Battle (cross domain integration) by exercising Air/Sea/Land targeting and clearance of fires concepts.

- JOA-017. The ability to mask the approach of joint maneuver elements to enable those forces to penetrate sophisticated antiaccess systems and close within striking range with acceptable risk. Enables the seizure of key terrain to facilitate JRSOI of follow on forces. The rotational deployment of this capability also enables theater engagement and Phase 0 operational access.

Protection

- JOA-018. The ability to defeat enemy targeting systems, including their precision firing capabilities. Development and deployment of this capability enables defeat of opponent naval, naval air, and amphibious forces in the joint operational area (JOA).

- JOA-019.The ability to provide expeditionary missile defense to counter the increased precision, lethality, and range of enemy antiaccess/area-denial systems. Although this munition is not an AMD asset, it provides highly maneuverable and low signature targeting problem for any adversary that counters the precision, lethality, and range of the enemy A2AD system.

- JOA-021. The ability to protect forces and supplies deploying by sea and air. The development and deployment of this capability provides a scalable option to protect sea lines of communication and intermediate staging bases from naval, naval air, and amphibious threats. 
- JOA-024. The ability to deploy, employ, and sustain forces via a global network of fixed and mobile bases to include sea-basing. Same as above

Information

- JOA-027. The ability to inform and influence selected audiences to facilitate operational access before, during, and after hostilities. The development and deployment of this capability as part of existing theater security cooperation programs provides a demonstration of US commitment to the region and their mutual defense interests.

Engagement

- JOA-028. The ability to develop relationships and partnership goals and to share capabilities and capacities to ensure access and advance long-term regional stability. As noted in "Employing Land-Based Anti-Ship Missiles in the Western Pacific," a LASM would "not only provide a potent capability to combatant commanders but also opportunities to engage Asian partner nations in the region through security cooperation efforts that target this capability." 112

- JOA-029. The ability to secure basing, navigation, and overflight rights and support agreements from regional partners. A LASM enables this capability by broadening the alliances and partnerships with regional countries in accordance with current US strategy for the region. ${ }^{113}$

- JOA-030. The ability to provide training, supplies, equipment, and other assistance to regional partners to improve their access capabilities. See JOA-028

${ }^{112}$ Kelly, Atler, Nichols, and Thrall. Employing Land-Based Anti-Ship Missiles in the Western Pacific, 16.

113 Ibid., 17. 
Bibliography

Anderson, Duncan. The Falklands War, 1982. Oxford, England: Osprey, 2002.

Army Doctrine Publication 3-0, Unified Land Operations. Washington, DC: Government Printing Office, 2012.

Boisot, Max and Bill Mckelvey. 2010. "Integrating Modernist and Postmodernist Perspectives on Organizations: A Complexity Science Bridge." Academy of Management Review 35, no. 3: 415433. Business Source Complete, ebscohost (accessed august 15, 2014).

Chandrashekar, S., N. Genesh, C.R. Raghunath, Rajaram Nagappa, N. Ramani, and Lalitha Sundaresan. “China’s Anti-Ship Ballistic Missile Game Changer in the Pacific Ocean.” International Strategic \& Security Studies Programme (ISSP).

Citino, Robert M. The German Way of War: From the Thirty Years' War to the Third Reich. Lawrence: University Press of Kansas, 2005.

Clapper, James R., and U.S. Office of the Director of National Intelligence. 2013 Worldwide Threat Assessment of the Us Intelligence Community. Edited by Kurtis Toppert. Charleston, SC: Penny Hill Press Inc, 2013.

Clausewitz, Carl Von. On War. Translated and edited by Michael Howard and Peter Paret. Princeton, NJ: Princeton University Press, 1984.

Commission, U.S.-China Economic and Security Review. China's Active Defense Strategy and Its Regional Impact. Washington, DC: CreateSpace Independent Publishing Platform, 2011.

Dastrup, Boyd L. "US Army Field Artillery Center and School Annual Historical Review 1 January 1986 Through 31 December 1986.” USAFACS Historical Monograph Series. Fort Sill. Oklahoma: Center of Military History, 1986.

. "Modernizing the King of Battle 1973-1991.” USAFACS Historical Monograph Series. Fort Sill, Oklahoma: Center of Military History, 2003.

Dolman, Everett C. Pure Strategy: Power and Principle in the Space and Information Age. Frank Cass: New York, NY, 2005.

Dorner, Deitrich. The Logic of Failure: Recognizing and Avoiding Error in Complex Situations. Preseus Books Group: Cambridge, MA, 1996.

Field Manual 100-5, Operations. Washington, DC: Government Printing Office, 1986.

Field Manual 6-20, Fire Support in the AirLand Battle. Washington, DC: Government Printing Office, 1988.

Joint Publication 5-0, Joint Operation Planning. Washington, DC: Government Printing Office, 2011. 
Freedman, Thomas. Deterrence. Cambridge, MA: Polity Press, 2004.

Gordon IV, John \& John Matsumura. The Army's Role in Overcoming Anti-Access and Area Denial Challenges. Santa Monica, CA: RAND Corporation, 2013.

Hailan, Ye. "Safe Seas." Beijing Review 52, no. 13 (April 2009): 10-11. Accessed on July 29, 2014 from EBSCOhost

Hastings, Max and Simon Jenkins. The Battle of the Falklands. New York: W.W. Norton, 1983.

Hughes, Wayne. Fleet Tactics and Coastal Combat. Annapolis, MD: Naval Institute Press, 2000.

Isserson, G.S. “The Evolution of Operational Art,” trans. Bruce W. Mennin. Fort Leavenworth, KS: SAMS Theoretical Special Edition, 2005.

Janosko, Theodore \& Robert G. Cheatham, Jr. "The Sound of Thunder: VCA in Operation Iraqi Freedom. Field Artillery Magazine (September-October 2004). Fort Sill, OK, 2004.

Jervis, Robert. System Effects: Complexity in Social and Political Life. Cambridge, MA: Cambridge University Press, 1997.

Johnston, Al. "Cultural Realism and Strategy in Maoist China,” in PJ Katzenstein, The Culture of National Security: Norms and Identity in World Politics. New York: Columbia University Press, 1996.

Keck, Zackary. “US Tests New Stealthy Long Range Anti-Ship Missile.” The Diplomat. (November 15, 2013). Accessed July 29, 2014, http://thediplomat.com/2013/11/us-tests-new-stealthy-long-rangeanti-ship-missile/

Kelly, Terrence K., Anthony Atler, Todd Nichols, and Lloyd Thrall. Employing Land-Based Anti-Ship Missiles in the Western Pacific. Santa Monica, CA: RAND Corporation, 2013.

Kipp, Jacob. “The Origins of Soviet Operational Art 1917-1936,” in Historical Perspectives on Operational Art, Washington, DC: CMH, 2005.

Knox, MacGregor and William Murray. The Dynamics of Military Revolution, 1300-2050. London, England: Cambridge University Press, 2001.

Lindgren, Mats and Hans Banhold. Scenario Planning: The Link Between Future and Strategy. Baskingstoke, Hampshire: Palgrave Macmillan, 2003.

Lockheed Martin. “Lockheed Martin Conducts Second Successful LARS Flight Test.” (November 14, 2013). Accessed June 23, 2014, http://www.lockheedmartin.com/us/news/pressreleases/2013/november/mfc-111413

Luttwak, Edward N. Strategy: The Logic of War and Peace. Cambridge, MA: Harvard University Press, 1987

McMaster, H.R. Lecture, Command and General Staff College, Fort Leavenworth, KS, August 14, 2014. 
Millet, Allan R. and Williamson Murray. Military Effectiveness in the Interwar Period. Boston, MA: Unwin Hyman, 1988

Montgomery, Evan B. “China’s Missile Forces Are Growing: Is It Time to Modify the INF Treaty?” The National Interest. (July 2, 2014). Accessed on July 9, 2014, http://nationalinterest.org/feature/chinas-missile-forces-are-growing-it-time-modify-the-inf-10791

Mulvenon, James and David Finkelstein. China's Revolution in Doctrinal Affairs: Emerging Trends in the Operational Art of the Chinese People's Liberation Army. Alexandria, VA: CNA Corporation, 2005.

Office of the Director of National Intelligence. National Intelligence Council. Global Trends 2030: Alternative Worlds. Accessed on July 10, 2014, http://www.dni.gov/index.php/about/organization/national-intelligence-council-global-trends

Posen, Barry. "Command of the Commons: The Military Foundation of U.S. Hegemony,” International Security 28, no. 3 (June 2003): 8. Accessed March 26, 2014, http://web.mit.edu/ssp/people/posen/commandofthecommons.pdf

Ralston, Bill and Ian Wilson. The Scenario Planning Handbook: Developing Strategies In Uncertain Times. Mason, OH: South-Western, 2006.

Rice, Condoleeza. “The Making of Soviet Strategy,” in Makers of Modern Strategy: From Machiavelli to the Nuclear Age, edited by Peter Paret, 648-76. Princeton, NJ: Princeton University Press, 1986.

Rogers, Clifford J. "The Military Revolutions of the Hundred Years' War." Journal Of Military History 57, no. 2: 241-278. America: History and Life with Full Text, EBSCOhost. Accessed July 10, 2014, http://people.reed.edu/ ahm/Courses/Reed-POL-359-2011S3_WTW/Syllabus/EReadings/03.2/03.2.Rogers1993The-Military.pdf

Romjue, John L. From Active Defense to AirLand Battle: The Development of Army Doctrine, 19731982. United States Army Training and Doctrine Command. Washington, DC: Government Printing Office, 1984.

Schobell, Andrew, David Lai and Roy Kamphausen. Chinese Lessons From Other Peoples’ Wars. US Army War College, Carlisle, PA: Strategic Studies Institute, 2011.

Strategic Initiatives Group. Imagining Defeat in 2030: Mitigating Strategic Surprise to the US Army by Envisioning the Worst. School of Advanced Military Studies (SAMS): Fort Leavenworth, KS, 2014.

Thomas, Jim. "Why the U.S. Army Needs Missiles." Foreign Affairs. (April 3, 2013). Accessed June 23, 2014, http://www.foreignaffairs.com/articles/139119/jim-thomas/why-the-us-army-needsmissiles

US Congress. Senate. Committee on US-China Economic and Security Review Commission. China's Navy Extends its Combat Reach to the Indian Ocean. $28^{\text {th }}$ Cong., $1^{\text {st }}$ sess., 2014. S. Rep.

US Department of Defense. 2012 US Department of Defense Strategic Guidance - Sustaining US Global 
Leadership: Priorities for the 21st Century Defense. Washington, DC: Government Printing Office, 2012.

2012 Army Strategic Planning Guidance. Washington DC: Government Printing Office, 2012.

. Air-Sea Battle: Service Collaboration to Address Anti-Access and Area Denial Challenges.

Washington, DC: Government Printing Office, 2013

- Annual Report to Congress: Military and Security Developments Involving the People's Republic of China 2013. Washington, DC: Government Printing Office, 2013.

. Capstone Concept for Joint Operations: Joint Force 2020. Washington, DC: Government Printing Office, 2012.

. Chairman of the Joint Chiefs of Staff Instruction 3170.01H. "Joint Capabilities Integration and Development System.” (January 10, 2012). Accessed June 1, 2014, https://dap.dau.mil/policy/Documents/2012/3170_01.pdf

. Gain and Maintain Operational Access Event Report. Fort Leavenworth, KS: Mission Command Battle Lab, 2012.

. Formal Investigation Into the Circumstances Surrounding the Attack on the USS Stark on 17 May 1987. Accessed on July 30, 2014, http://www.jag.navy.mil/library/investigations/uss\%20stark\%20basic.pdf

- Joint Operational Access Concept. Washington, DC: Government Printing Office, 2012.

. TRADOC Pam 525-3-4 The United States Army Functional Concept for Fires 2016-2028. Washington, DC: Government Printing Office, 2010. Accessed on June 24, 2014, http://www.tradoc.army.mil/tpubs/pams/tp525-3-4.pdf

. US Department of Defense. Unified Quest 2013: Deep Future Wargame 2030-2040 Executive Report. Carlisle Barracks, PA: US Army War College, 2013, 24.

US Department of the Navy. Lessons of the Falklands. Washington, DC: Office of Program Appraisal, 1983. Accessed on May 21, 2014, http://handle.dtic.mil/100.2/ADA133333 on May 21, 2014

Wilkenfeld, Jonathan, Michael Brecher, and Sheila Rosen, Crisis in the Twentieth Century: Handbook on Foreign Policy Crisis. New York: Pergamon, 1988.

Yiping, Ding and Shijie Jaijun Shi. World Naval History. Beijing, China: Sea Tides Press, 2000.

Yoshihar, Toshi and James R. Holmes, Red Star Over The Pacific: China's Rise and the Challenge to U.S. Maritime Strategy. Annapolis, MD: Naval Institute Press, 2010.

Zedong, Mao. Strategic Problems of China's Revolutionary War. Peking, China: Foreign Language Press, 1954. 
